University of Louisville

ThinkIR: The University of Louisville's Institutional Repository

Electronic Theses and Dissertations

$5-2009$

\title{
In the wor(I)d but not of it : literacy practices of an Amish community in southeast Ohio.
}

Tabetha Adkins

University of Louisville

Follow this and additional works at: https://ir.library.louisville.edu/etd

Part of the English Language and Literature Commons

\section{Recommended Citation}

Adkins, Tabetha, "In the wor(I)d but not of it : literacy practices of an Amish community in southeast Ohio." (2009). Electronic Theses and Dissertations. Paper 14.

https://doi.org/10.18297/etd/14

This Doctoral Dissertation is brought to you for free and open access by ThinkIR: The University of Louisville's Institutional Repository. It has been accepted for inclusion in Electronic Theses and Dissertations by an authorized administrator of ThinkIR: The University of Louisville's Institutional Repository. This title appears here courtesy of the author, who has retained all other copyrights. For more information, please contact thinkir@louisville.edu. 
IN THE WOR(L)D BUT NOT OF IT:

\section{LITERACY PRACTICES OF AN AMISH COMMUNITY IN SOUTHEAST OHIO}

By

Tabetha Adkins

B.A., Marshall University, 2003

M.A., University of Louisville, 2005

A Dissertation Submitted to the Faculty of the Graduate School of the University of Louisville in Partial Fulfillment of the Requirements for the Degree of

Doctor of Philosophy

Department of English University of Louisville, Louisville, Kentucky

May 2009 
Copyright 2008 by Tabetha Adkins

All rights reserved 
IN THE WOR(L)D BUT NOT OF IT:

LITERACY PRACTICES OF AN AMISH COMMUNITY IN SOUTHEAST OHIO

\author{
by \\ Tabetha Adkins \\ B.A., Marshall University, 2003 \\ M.A., University of Louisville, 2005 \\ A Dissertation Approved on
}

April 6, 2009

by the following Dissertation Committee:

Dissertation Director 


\section{DEDICATION}

This dissertation is dedicated to my granny and my grampa, June and Bill Proklevich, for their consistent enthusiasm, support, and love. As grampa likes to say, you are loved.

And to my mom, Robyn Miller, for her astonishing sacrifices and courage. At the end of . first grade, a woman at Kopy Kat boutique asked me how much longer I'd be in school. I said at least fifteen years. She was confused, and I vividly remember you saying, "Yes. My daughter will go to college." Thank you so much for that confidence. 


\section{ACKNOWLEDGMENTS}

Students have few opportunities to properly thank mentors, colleagues, family members, and friends for the emotional, physical, and intellectual support they offer. The first person who must be acknowledged for the success of this dissertation is Dr. Karen Kopelson. When we first talked about this project, I feared that my outsider status would exclude me from the Amish community. Dr. Kopelson recognized the potential in this project and encouraged me to take the risk. I am not exaggerating when I say this project would not exist without Dr. Kopelson's urging. In these six years of graduate school, I have often turned to her for career advice, encouragement, and even support during personal crises. She is the kind of mentor who returns 2:00 A.M. e-mails at 2:15 A.M. She has spent countless hours working with me on my dissertation this semester despite the fact that she is on sabbatical. She compliments me when I succeed and helps me learn from my mistakes. I have had the privilege of working with many outstanding faculty members during my time at University of Louisville, but the six-year working relationship I have developed with Dr. Kopelson was paramount to my development as a scholar.

I am also very pleased to have this opportunity to thank the incredible committee who helped make this dissertation experience so positive. Dr. Bronwyn Williams is the kind of scholar, teacher, advisor, and human being I hope to be. Dr. Carol Mattingly has been a mentor and friend to me since my first year at the University of Louisville. Dr. 
Annette Harris Powell always makes me feel very good about my research. Dr. Katrina Powell's wonderful book The Anguish of Displacement: The Politics of Literacy in the Letters of Mountain Families in Shenandoah National Park was a formative influence on this project, and the feedback she has kindly offered has informed my future research plans. I also want to recognize faculty members who were not involved in this dissertation but were influential in my graduate career, specifically Dr. Debra Journet, Dr Joanna Wolfe, and Dr. Anthony O'Keeffe.

I must also thank a flock of friends and colleagues whose support has been incredible: Dr. Kate Brown Warrington, Dr. Sonya Borton, Dr. Alanna Frost, Dr. Stephanie Fleisher, Linda Baldwin, Dr. Julie Myatt, Ryan Trauman, Matt Dowell, Patrick Corbett, Steve Reed, Dr. Anca Iancu, Michelle Bachelor Robinson, Phillip Blackmon, Simon Sangpukdee, Neil Norman, Branden Barker, Allison Cuyjet, Paul Brown, and especially my writing group members, Cindy Britt and James Romesburg. James and Cindy read every word of this dissertation with attention and interest, and I am so grateful for their scrutiny, support, and good humor. I want to also specifically mention the incalculable help and advice I received from Kate Brown Warrington, Sonya Borton, Cindy Britt, and Julie Myatt. And I can't talk about the support I've received from friends without mentioning my dear friend Erin Riedel who should be given a medal for the amount of time she spent listening to me talk about my dissertation and job search.

I especially want to acknowledge the support and love I receive from my family. My mom, Robyn Miller, has been my biggest cheerleader since the day I was born. (No spirit stick pun intended.) My grandparents, Bill and June Proklevich, check in with me most everyday just to see how I am doing. My brother, Bryan Adkins, makes me proud 
and helps keep my ego in check. My step-dad, Ernie, never fails to remind me how proud he is of me. As to my future family, I could not have completed this study without the generosity Bill and Jeanie Shato.

While I cannot mention the Amish and Mennonite participants of this study by name, I want to state that I was astounded by their giving spirit. Despite their busy lives, not one person refused to spend time talking with me. I look forward to working with and writing about this community for years to come.

And finally, thank you to my partner, William Paul Shato, for showing me love and introducing me to this wonderful, strange life. 


\section{ABSTRACT \\ IN THE WOR(L)D BUT NOT OF IT: \\ LITERACY PRACTICES OF AN AMISH COMMUNITY IN SOUTHEAST OHIO \\ Tabetha Adkins}

April 6, 2009

Following in the tradition of scholars who treat literacy in context such as

Deborah Brandt, Shirley Brice Heath, and David Barton and Mary Hamilton, I conducted my dissertation research not in an academic classroom but in the valleys of Hanley, a (pseudonym for a) town in southern Ohio, where I visited Amish homes, farms, and businesses. Using Brandt's model in Literacy in American Lives, I interviewed 25 Amish men, women, and children to study the uses of literacy in school, church, work, and daily life. I also attended community events such as an auction and a wedding to observe ritualistic literacy practices. Observing community members in their home environments helped me to gain a better understanding of the importance of language and literacy in everyday Amish life. In addition, I read The Budget, the Amish and Mennonite International weekly newspaper, for one year.

The result of this research is my dissertation "In The Wor(1)d But Not Of It: Literacy Practices of an Amish Community in Southeast Ohio," in which I argue that the 
normalizing effect of English literacy in the United States has changed Amish language and literacy practices, despite the Amish community's desire to live separately from mainstream culture. The English-only imperative in the United States has permeated Amish ideas about the value of English in their daily lives and, therefore, has devalued their home language, Pennsylvania Dutch. Some Amish denominations have completely abandoned Pennsylvania Dutch, while others maintain the language in order to preserve their heritage and faith. Those who do maintain the language, however, are aware that the community's fluency in the language decreases with each generation and that an "alarming amount of English" has pervaded the Pennsylvania Dutch lexicon. I also argue that the Amish values of collaboration and putting community before self have directly influenced models of Amish education, church hierarchy, community leadership, and the composition of texts that represent the Amish. 


\section{TABLE OF CONTENTS}

PAGE

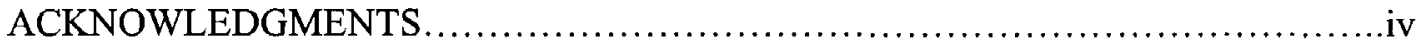

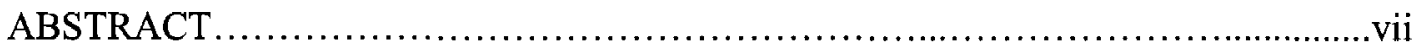

CHAPTER

1. IN THE[IR] WORLD BUT NOT OF IT: GROUNDS, METHODS, AND IMPLICATIONS FOR STUDYING AMISH LITERACY. 1

2. "THE CHRISTIAN THING TO DO": COMMUNITY AND COLLABORATION AS A MODEL FOR AMISH TEACHING, LEARNING, AND LIVING

3. "THE LANGUAGE ON THE TIP OF MY TONGUE": THE ROLES AND SPHERES OF PENNSYLVANIA DUTCH, ENGLISH, AND AMISH GERMAN

4. "TO EVERYONE OUT THERE IN BUDGET LAND": THE NARRATIVE OF COMMUNITY IN THE INTERNATIONAL WEEKLY AMISH NEWSPAPER, THE BUDGET.

5. "WHY DO YOU WANT TO KNOW ABOUT OUR READING AND WRITING?": CONCLUSIONS, IMPLICATIONS, AND REFLECTIONS

REFERENCES

\section{APPENDENICES}

A. ADULT INTERVIEW QUESTIONS. 115

B. CHILD INTERVIEW QUESTIONS 116

C. SCRIBE INTERVIEW QUESTIONS 
D. TEACHER INTERVIEW QUESTIONS......................118

E. ADULT CONSENT FORM.....................................119

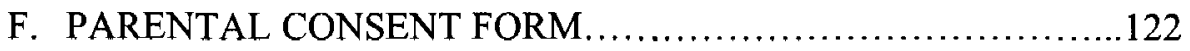

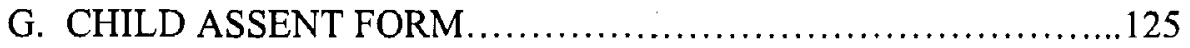

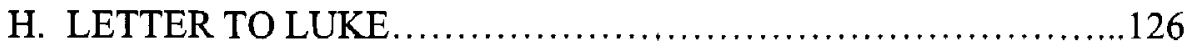

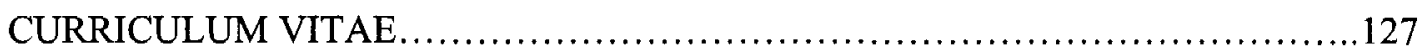




\title{
CHAPTER ONE
}

\section{IN THE[IR] WORLD BUT NOT OF IT:}

\section{GROUNDS, METHODS, AND IMPLICATIONS FOR STUDYING}

\begin{abstract}
AMISH LITERACY
This dissertation offers an analysis of the literacies and languages of a population rarely addressed by writing scholars: the Amish, a multilingual religious group residing mostly in rural American areas. I argue that Amish values of collaboration and community have served as models for Amish literacy practices. Despite the Amish community's desire to be "in the world but not of it" and live separately from mainstream culture, they too have been normalized by the force of literacy—and especially "English Only" literacy-in America. ${ }^{1}$ I show that as a culture, the Amish try to exist in two different worlds; the community wants to live separate from the mainstream, but they also believe that as Americans, their privileged language must be English. The objectives of this dissertation are to illustrate how the collaborative values of the Amish have affected literacy practices at home and in school and to reveal the result of this model on Amish languages. Since literacy acts are only meaningful in their social contexts, this chapter will begin with an introduction to the social contexts upon which this study is based, including a short history of the Amish in the United States and a discussion of my

1 "In the world but not of it" is a phrase that comes from I Peter 2:11 which tells Christians to show their faith through their actions. As I will show, this verse is a major tenant of Amish faith.
\end{abstract}


own coming to know the Amish community in "Hanley," Ohio. ${ }^{2}$ This introduction will be followed by an analysis of how this study is situated within the broader conversations of new literacy studies. I will then relate the methods used to gather data for the study and end the chapter with an abstract of the chapters that follow.

\section{Who Are the Amish, and Why Study Their Literacy Practices?}

Amish communities in the United States are trilingual; they use the Pennsylvania Dutch language at home, the "Old" Amish German language in religious services, and English in (non-Amish) public. Like many non-native English speakers living in the United States, the history of how the Amish came to be in the United States is one of religious persecution and of a people who were desperate to flee war and poverty. In the Eighteenth Century, the Amish, in an effort to maintain their plain lifestyle that they are still known for today, fled from Switzerland and Germany to southeast Pennsylvania for its rich farmland and privacy. Since then, the Amish have settled in 21 American states and Central American countries, especially in Belize. Amish people of the Mennonite denomination today also perform missionary work all over the world. As John A. Hostetler, the foremost scholar of Amish culture, shows in his book Amish Society, members of the Amish faith can be divided into three major categories: Old Order Amish, New Order Amish, and Mennonites (or "Beachy Amish"). These categories emerged after the Amish Ministers' Conference in 1878 when these groups failed to come to a consensus about what it meant to be a follower of Christ and the Amish faith

\footnotetext{
${ }^{2}$ All names of people and cities are pseudonyms. I used biblical names for Amish participants.
} 
(281). All three of these groups are part of a larger group called Anabaptists. In this dissertation, I use the term Amish to talk about all three groups.

Despite the fact that the Amish are scattered throughout the world, community unity is an important element of Amish identity, and while the Amish make very little use of modern technology, one technological advance has greatly enhanced community unity: newspaper printing. Today, most Amish families subscribe to The Budget, a weekly newspaper published in Sugar Creek, Ohio (approximately 200 miles from Hanley) constructed entirely of letters written by Amish community members detailing the events of their respective community. ${ }^{3}$ I write about The Budget in detail in chapter four.

There is an extensive precedent in the field of literacy studies for studying a group like the Amish. Writing scholars have shown great interest in exploring the literacy practices of marginalized groups, including Appalachian women (Sohn), fishing communities in Maine (Lofty), the Hmong (Duffy), the displaced families living in Shenandoah National Park (Powell), transnational Mexican communities (Guerra), and the Nukulaelae (Besnier). Kim Donehower, Charlotte Hogg, and Eileen Schell call for scholars to re-direct their attention specifically to literacy practices that occur in rural communities. They argue that typical studies of literacy focus only on urban or city literacies which exclude the experiences of people living outside of cities, leading to classist or unrealistic ideas about readers, writers, and students. This dissertation follows in the tradition of these studies that have been interested in, as David Barton and Mary Hamilton put it, "the ways in which literacy acquisition connects with sociocultural background" (4).

\footnotetext{
${ }^{3}$ All newspaper articles referenced in this dissertation come from The Budget. I reference Budget articles and letters by date and page number.
} 
Literacy practices that occur outside academic settings have also gained a great deal of attention in recent literacy studies scholarship. This shift away from studying only what occurs in the classroom is part of an effort to, as Deborah Brandt says, "treat literacy 'in context"' (Literacy in American Lives 4). Brandt argues that giving attention to literacy practices that occur outside of classrooms is necessary because "schools are no longer the major disseminators of literacy" (198). Instead, since the social purpose of literacy has changed with competition and business, "diversification of work, especially parental work, brings various kinds of materials, instruments, and other resources into homes where they can be appropriated into teaching and learning" (198). Yetta M. Goodman also shows that most literacy learning does not occur in schools, and that educators should examine "the influences of the social world of children both at home and in school on their writing" (vii).

This dissertation focuses primarily on the way Amish values shape and inform Amish literacy practices. In "Sponsors of Literacy," Brandt acknowledges the way in which the economic benefits of literacy have determined the social value of literacy:

[...] I do not wish to overlook the very different economic, political, and education systems within which U.S. literacy was developed. But where we find the sponsoring of literacy, it will be useful to look for its function within larger political and economic arenas. Literacy, like land, is a valued commodity in this economy, a key resource in gaining profit and edge. This value helps to explain, of course, the lengths to which people will go to secure literacy for themselves or their children. But it also explains why the powerful work so persistently to conscript and ration the 
powers of literacy. The competition to harness literacy, to mange, measure, teach, and exploit it, has intensified throughout the century. (558-9)

I use Brandt's concept of literacy as a commodity or resource as a frame through which to examine literacy practices in this Amish community. Similarly, J. Elspeth Stuckey argues the "usual speculations about the nature and need for literacy are misguided" and what seems like values for reading, writing, and speaking in this country are simply veiled values for the ability to pay (vii). I argue in this dissertation that while Amish language and literacy have certainly been shaped by economic conditions, the values of collaboration, maintenance of community, and preservation of faith create the uniquely Amish literacy practices at the center of this study.

The final element of social context I will discuss here is the way in which I came to know my contacts. I am not Amish. My fiancé, also not Amish, grew up in Hanley where his family owned a farm. In the early nineteen-nineties, Amish families began to move into the area, and his family (and especially his father, Thomas) befriended their new neighbors. I depended on these relationships for gaining access to interview participants and information. Thomas took on the role of "advertising" my study to the community; several months before my data collection period, he told all his Amish friends about my upcoming visit and study. Rebekah, my fiancé's mother, introduced to me to every interview participant and was present at 22 of 25 interviews. Without these relationships, this project would have been impossible.

\section{Methods}


My primary concern in designing this project was to engage the community in a responsible, ethical, and reflexive way. I knew that Amish participants could potentially and understandably resist my attempts to learn about their reading and writing practices, especially since, as a doctoral candidate at a university, I represent state-sanctioned education and institutions. Historically, the Amish have fought for the rights to educate their children in the manner dictated by their traditions and faith, and this fight was especially brutal in Ohio where, as Hostetler and Gertrude Enders Huntington show in Amish Education: Education in the Family, School, and Community, Amish fathers were imprisoned for refusing to send their children to state-supported schools (39). The 1972 Supreme Court decision Wisconsin v. Yoder gave Amish families the legal right to educate their children as determined by their faith and traditions, but many of the participants in this study attended school (both Amish parochial and state schools) before Wisconsin v. Yoder and remembered the struggles their fellow-Amish suffered at the hands of local governments and school boards. It was important to me, then, for participants to understand that my goal was not to make a value judgment on their education model, literacy practices, or lifestyles. With this in mind, I tried to create a research design that was as transparent and reflexive as possible.

Scholars of feminist research methodologies greatly influenced the design of this study. When conducting research, I took as many notes about the context of the interview as possible because like Kathleen Blake Yancey, I feel that context matters. I include the detailed descriptions of interview conditions throughout the dissertation. In writing the results of my study, I followed Judith Roof and Robyn Wiegman's tips for speaking for others, especially focusing on their advice to "question [my] position to 
those [I am] speaking for and analyz[ing] the possible results of what $[\mathrm{I}]$ say" (4). I also benefited from Sondra Perl's experience with speaking for others, of which she writes:

Since those I am attempting to research are not me, but become what is currently often referred to as 'the other,' my understanding of their worlds always entails an imaginative leap, one we too often ignore in our current research and writing... researchers need to show more of themselves at work, share more of the data they collect, make tapes, videos, and transcripts available at research seminars and conferences, and through online networks, to let all interested parties in on the ground level. (95)

In order to "show [myself] at work," I kept a dissertation weblog (available at http://adkinsdiss.blogspot.com/) and presented a paper on my research methods at the 2009 Conference on College Composition and Communication in San Francisco, California.

Information for this dissertation was obtained in three ways. First, I read The Budget, the International Amish Newspaper, for one year. Budget issues were coded for re-occurring themes. ${ }^{4}$ (An extensive description of The Budget can be found in chapter four.) Second, I interviewed twenty-five Amish and Mennonite men, women, and children living in the Hanley area using open ended, guide approach interviews (Patton 343). (See these questions in Appendices A through D.) This method is one where, according to Patton, "topics and issues to be covered are specified in advance, in outline

\footnotetext{
${ }^{4}$ These themes from The Budget include: humor/entertainment, medical advice, language, religion, family, school, special community events, church news, births, deaths, accidents, weddings, reading, writing, community portrayal, religious ethos, The Budget as an information source, conventions, audience, discussion of The Budget, and writing for The Budget.
} 
form; the interviewer decides sequence and wording of questions in the course of the interview" (349). I chose this method because I wanted to be sure that the data was comprehensive while still allowing room for discussion and context to shape the results. The 25 interviews took place over a three-week span in June 2008 and notes from these interviews were coded for reoccurring themes. ${ }^{5}$

I obtained Internal Review Board (IRB) approval before beginning the interviews (study number 08.0157 , approved 3/28/2008). Upon gaining this approval, I first approached Matthew, a bishop for the community, and asked his permission to interview him. I wanted Matthew to understand the nature of my presence in the community so that as a leader of the community, he could give guidance to others who had questions about my intentions. Among ethnographers, there is a precedent for interviewing community leaders before engaging with the community as a whole. Sylvia Scribner and Michael Cole state that "in each town we began our interviewing with the chief and the elder statesmen, as a courtesy and because they usually requested that we begin in this way" (45). My experience with the community leads me to believe that this was the right decision, because if Matthew had heard second-hand that an outsider was asking questions about the community's reading and writing, his reaction could have had a negative affect not only on my study but also on my relationship with the Amish community members.

During this first interview, I could see that there were problems with my informed consent forms. (See IRB Consent and Assent Forms in Appendices E through G.)

\footnotetext{
${ }^{5}$ Interview themes include: language, religion, school, collaboration, learning, teacher, English, Pennsylvania Dutch, German, ancestry, family, family, church, The Budget, reading at home, writing at home, reading at church, writing at church, reading at work, writing at work, community, non-Amish, training, and business exchanges.
} 
Matthew had many questions about the form. He could not understand why categories like "Privacy," "Risk," and "Compensation" were present if all I wanted to do was talk about reading and writing. I allowed him to read the questions I wanted to ask, and seeing these questions put him at ease. I explained that the consent form uses academic conventions that are required by the university. However, it was clear that in composing this form, I had considered the wrong audience; I was writing for the IRB office, not for the Amish. Although the form was relatively free from "academic jargon," phrases like "the data will be stored on a password-protected computer" and the inclusion of telephone numbers should have been revised. I learned quickly that in a community where computers are absent, there is no perceived difference between a computer and the Internet, so community members thought I was placing their personal data on the Internet. Matthew suggested that I conduct the interviews before asking for signed consent so that participants would know that the questions were not personal in nature and truly understand that the terms "Privacy" and "Risk" were conventions of the genre. The experience of collaborating with Matthew on this decision adheres to Gesa Kirsch's call to open "up the research agenda to subjects, listen to their stories, and allow them to actively participate as much as possible, in the design... of research" (257). I followed Matthew's advice and decided that if participants would not sign the form after the interview, I would simply throw out my notes from their interview.

A second complication of the data-gathering process was one I anticipated and prepared for. Ethnographers generally agree that a tape recorder is an essential tool of good ethnography. Charlotte Davies asserts: 
The use of a tape recorder in ethnographic interviewing is almost universally accepted and unreservedly advocated. It is probably less intrusive and destructive of open and natural conversation than having an ethnographer taking notes, and it is infinitely more reliable than memory, no matter how good, of what was said. Furthermore, its use allows the ethnographer to be much more aware of other aspects of the interaction that cannot be captured by sound recording, and to enter more fully into the development of the interview. (114)

The problem this method created is that the Amish do not allow themselves to be photographed or audio recorded since an audio recording is, in a sense, a photograph of one's voice. ${ }^{6}$ Andrea Fishman addresses this conundrum in her own study of the Amish, stating that she was given permission to use a tape recorder but found that "the big black box" was too much of a distraction to her participants, who were not used to having such technology present (11-12). I therefore prepared to write with pen and paper participants' responses to my questions. I developed an elaborate note-taking code that allowed me to use symbols and abbreviations for commonly used terms like Amish, English, church, school, family, et cetera. At the end of every interview, I read my notes back to the participant to ensure I had not misunderstood any of their responses. After leaving an interview, I sat down immediately to write "reflective remarks" and to interpret my symbols and abbreviated notes into a longer narrative (Miles and Huberman 66). One month after the initial data gathering period ended, I returned to the community to attend

6 As Hostetler shows, the Amish object to being photographed "based on religious grounds, ranging from the prohibition of the graven image (Exod. 20:4-5) and a variety of other biblical teachings against a show of personal pride and vanity" (319). 
their annual auction held to raise money for the Amish parochial schools. I took this opportunity to follow-up with participants to ensure that they still wanted to be involved in my study and to ask follow-up questions if necessary.

Another research design element that I came to see as a very good decision was the absence of offered compensation. This decision was inspired both by my lack of funds to offer research participants and by the advice of my primary contact, Rebekah. She told me:

They never let me pay for anything because [her husband] helps them with their farms and gives them rides to town. They think they are indebted to us and want to show their gratitude whenever possible. Because they see you as part of our family, they won't let you pay them.

In hindsight, I also think participants would have been confused by the concept for which they were being paid. In this community, families make their money with labor, not with conversation or ideas. Academics, of course, are used to being paid for their ideas, but in the Amish community, this concept is a foreign one. This notion, like the language on the IRB form, serves as another example of the conflict between academic and Amish values. Instead of compensating individual participants for their time and responses, I decided to follow the advice provided by Katrina Powell and Pamela Takayoshi in their article, "Accepting Roles Created for Us: The Ethics of Reciprocity." Like Powell and Takayoshi, I wanted to find a research model that removed the power dynamics inherent in research. Most importantly, I wanted the Amish to benefit somehow from this experience. I decided that I could help the larger community by buying a quilt from their annual auction for which community members donate quilts, furniture, farm animals, and 
baked goods that are sold to support the schools for the entire school year. While this transaction was certainly to my advantage-I acquired a beautiful piece of art created by people I admire and respect-I came to see this arrangement as one the Amish would appreciate; the generosity of a few members of the community - those who decided to participate in the study - benefited the entire community, as my purchase helped support the community-sustained schools.

Interview participants were chosen based mostly on their willingness to participate. Of the 25 interview participants, 24 were adults, 19 of whom were Old Order Amish, and three were Mennonites. These three Mennonites were included because one (Samuel) writes for The Budget, one (Daniel) is formerly Old Order Amish, and one (Anna) is married to a former Amish man but has herself always been a member of the Mennonite church. One Amish child was interviewed for this study. I had intended to interview more children, but I found that my presence was too novel to children. I suspect, too, that most Amish children are nervous about speaking English with a native English speaker (or simply "English person" as the Amish refer to those who speak English as their primary or only language).

When I imagined how the interviews would take place, I pictured myself sitting with participants at their kitchen tables, talking without interruption for half an hour. But as many ethnographers report, this ideal scenario is rare whenever research occurs outside of the academy. Scribner and Cole explain thusly:

We planned to have interviews conducted individually, and so they were. But individual sessions were not always private sessions. Every effort was made to secure quiet and privacy for the respondent by interviewing inside 
our rented houses; during especially hot spells, interviewers set up tables and chairs under trees remote from public walk-and-lounge ways. Even with these precautions, the novelty of the proceedings, especially for the first few days after our arrival in a town, tended to attract a fringe of interested observers. Like "sidewalk kibitzers," onlookers offered comments from time to time on the interview conversations. These intrusions represented little threat to the integrity of the information secured on personal history, but we had to take into account in our data analysis their potential contaminating influence on responses to attitude questions and experimental tasks. (46)

Indeed, I had the same intentions when I planned my research. These plans did not take into account, however, several factors that affected my research experience. First of all, I underestimated the hectic schedule of the average Amish man, woman, and child. Instead of finding a quiet place to sit and talk, participants found time for our chats between planting rows of corn, while completing tasks for the upcoming school auction, while hand-stitching quilts, and during the clean-up from a sibling's wedding. During the first day of interviews, I quickly realized that I wouldn't always have the convenience of a kitchen table to spread out my interview materials, nor would I always be able to have the undivided attention of an interview participant. Instead, I found myself balancing my notebook on my hip while standing in a blacksmith shop or making funny faces at a crying baby. Like Scribner and Cole, I did not feel that these interview conditions affected the integrity, honesty, or quality of the answers participants provided. Instead, I 
felt that this gave me a better understanding of the participants' lives and created a more organic research atmosphere.

Secondly, while I anticipated that the fact that I am unfamiliar, not Amish, and curious would make some participants uneasy, I was surprised to find that the presence of my primary informant, Rebekah, put many participants at ease. When she volunteered to take me to different Amish homes and businesses, I imagined her as a silent observer who introduced me to potential interview participants and then waited in the car. Instead, Rebekah stayed to watch the interviews - she was present at 22 of the 25 interviewsand at times, she engaged in conversation with the participants, especially when religion became the topic of conversation. For example, at the end of my interview with Matthew, she asked him if the Amish church practiced full submersion in their baptism. He answered that they did not but that he did not think there was "anything wrong with" full submersion. Rebekah, too, assured him that she did not think anything was wrong with his method, either, and they began to talk more about their religious beliefs. Matthew even asked Rebekah if she thought he had disobeyed Matthew Chapter Six, which commands Christians to avoid bragging. Matthew was afraid that his discussion of his community's language and education could be perceived as boastful.

On another occasion, an interview with Joseph, a Budget scribe, was not going as well as I had hoped. Joseph had been interviewed by a college student at The Ohio State University several years earlier when his son was a patient at the University's hospital. This student had asked Joseph many embarrassing questions and had conducted the interview in a private room; the entire experience made Joseph uneasy and angry. This occurrence made him distrustful of people asking for interviews, and especially of people 
from universities. I assured him that I had the utmost respect for the people of this community and mentioned specifically the kind treatment I had received from the Amish and Mennonite members of the family when a member of my fiancé's family died the previous summer. Seeing that Joseph could relate to this, Rebekah added that she had more Amish friends than non-Amish friends and that she really enjoyed getting to know the Amish people in the neighborhood. This statement seemed to comfort him, and Joseph then allowed me to continue the interview. He even seemed to enjoy our conversation.

When I reflected on this later and asked Rebekah about her comments to both Joseph and Matthew, she said that she felt she could help. And while many scholars of research methods and ethics might argue that Rebekah's influence on the interviews may have negatively affected the outcome, I argue that the social conditions present in this community create a unique research situation for which any research methods class could not prepare me. The value placed upon privacy and preserving a way of life force the Amish to be careful about whom they interact with; as a result, it is important to know who people are. Knowing this, Rebekah always introduced me as her "future daughterin-law" and specified to which of her sons I am engaged.

Finally, like Scribner and Cole who were of great interest to the "sidewalk kibitzers" they met during their study, I sensed that I was a novelty during my time in the community. Whenever I interviewed parents in their homes, children peered shyly from the stairwells, lingered in the kitchen, or bravely sat right beside me and watched me carefully. Several neighbors asked Rebekah about the strange black car-mine-in her driveway. Rumors circulated throughout the community that I was putting everyone's 
information into a computer for anyone to see (because of the consent form language I already discussed). When I attended the wedding of one participant, many heads especially those of children-turned to watch as I entered the room. This phenomenon seemed unavoidable, though, and I simply tried to be as friendly as possible.

The greatest surprise of my data gathering experience was the enthusiasm and generosity with which I was met. Not one person refused an interview, and only three participants, Matthew, Joseph, and Luke, needed reassurance about my intentions. When designing this project, I had serious concerns that no one would agree to participate; I could not have prepared for how invested participants have become. Scribner and Cole's similar experiences led them to state:

It fascinated me why the Vai should, in the busiest season of the yearduring two of the worst farming years one could have picked-have spent a lot of time answering questions which had little to do with the essential business at hand... Not only did the majority of people eventually come, but when they got there they answered with great deliberation. (47)

I, too, experienced many interviews where participants gave great thought to the responses. Sometimes participants would respond to questions with, "Well, give me a second, I've never really thought about that," or "Wow, that's a tough question." On two occasions, participants said they wished they had saved an article from The Budget's Anniversary issue to share with me. Since my data collection period, many participants have asked my primary contacts about me, my research, and the progress of my dissertation. Some people have sent me presents (Ezekiel sent a mug with the name of his business printed on it; Caleb sent an article from a newspaper about a business 
pretending to use Amish artists to craft "Amish stoves"), and a group of women in the community are rumored to be creating a quilt to give me as a wedding present. Experiences like these-connecting with people, developing relationships-are what initially drew me to ethnography as a research method. While some scholars warn ethnographers of growing too close to participants for fear of "going native" (Paton 568), I would argue that in this case, my bond with the community only led to better results since familiarity and friendship, not degrees and institutional support, are what create credibility and trust in the Amish community.

The remainder of this dissertation seeks to address specific elements of literacy and language to show how the values of the Amish community have informed these practices. In “'The Christian Thing to Do': Community and Collaboration as a Model for Amish Teaching, Learning, and Living" (chapter two), I argue that the Amish prioritization of community and the tradition of collaboration inform the literacy practices of Amish people living in Hanley. Education, both at pedagogical and organizational levels, is collaborative. Students are taught to help one another, and students' success is a concern of the entire community. Students in Amish schools are required to speak English at all times, and teachers rely on communication among students to aid in English instruction. The way in which pre-school aged Amish children acquire the English language is often the result of exposure to English-speaking people, and the personal value in learning English is based on being neighborly to Englishspeaking people.

Chapter three is titled "'The Language on the Tip of My Tongue': The Roles and Spheres of Pennsylvania Dutch, English, and Amish German." Here I argue that Amish 
literacy and orality rely on four major ideals: religious faith, heritage, nationalism, and economic and personal utilitarianism. Religious beliefs motivate the Amish to maintain their home language, Pennsylvania Dutch, and to preserve religious ceremonies and texts in Amish German. Nationalistic ideas about English literacy in the United States have caused the Amish to conduct all written business in English and to abandon any writing in Pennsylvania Dutch and Amish German. Utilitarian values regarding uses of language have led the Amish to educate their children almost exclusively in English because, as the Amish understand, English literacy is necessary to their survival and acceptance in the United States. Despite the fact that the Amish want not to be "of this world," the use of English literacy is undeniably important in this country. As a result, English is the sole language used for written composition, Pennsylvania Dutch is an oral tradition, and Amish German fluency is on the decline throughout the Amish world.

In the fourth chapter, “'To Everyone Out There in Budget Land': The Narrative of Community in the International Weekly Amish Newspaper, The Budget," I show how The Budget, an Amish newspaper that circulates to Amish subscribers all over the globe, helps to create a sense of community among the larger Amish population. The Budget is made up of letters written in English by Amish men and women who refer to themselves as "scribes." These scribes are assigned by church leadership to report on the events of their neighborhoods either weekly or biweekly. The content of these letters includes a wide variety of topics such as local weather; birth, death, and marriage announcements; words of encouragement for readers; and responses to letters in previous issues. These letters use a conversational tone one might expect in a letter from a friend or family member. Because Amish church rules (or Orndung, as they are referred to in Amish 
German) do not allow church members to own modern appliances that would assist in communication, such as telephones or computers, letter writing and news printed in The Budget are often the only means of communication among friends and family members. Therefore, the worth of the Budget to the Amish community cannot be overstated, and as a result, the role of a Budget scribe is revered in the Amish community. Finally, in the concluding chapter, I review the arguments made in my dissertation, reflect on my findings, discuss the implications of these findings, and give suggestions for further research. 


\section{CHAPTER TWO}

\section{"THE CHRISTIAN THING TO DO":}

\section{COMMUNITY AND COLLABORATION AS A MODEL FOR AMISH TEACHING, LEARNING, AND LIVING}

In Hanley, Amish collaboration and sharing can be seen by simply driving down any winding hollow. Children help their mothers hang laundry on Monday afternoon. Teenage boys assist their friends in herding an escaped goat back to her field. English neighbors drive their Amish friends to the hardware store in town. Amish friends assist English (non-Amish) neighbors in installing drain pipes. Even at formal events like wedding receptions, every attendee helps with the after-supper cleaning by scraping his or her food onto the disposable tablecloth which is then rolled up by those seated at the table for disposal. In Hanley, people are not left to fend for themselves. Helping out neighbors and friends is a practice that this community takes very seriously.

It is not surprising, then, to see that this model of collaboration and caring for one's community carries over into the Amish and Mennonite models of education and literacy practices. In this chapter, I argue that the traditions of helping one's neighbor and working to preserve the community have influenced Amish education, language learning, and writing in the community of Hanley. I show that this model follows in the tradition of community values shaping and determining literacy practices. 


\section{"We Learned by Listening to the Older Kids": Collaboration in Amish Education}

During the interviews for this study, I asked each participant to explain how they came to speak and understand all the languages-Pennsylvania Dutch, Old German, and English-essential to Amish life. This question inevitably led to discussion of experiences in school because, in the Amish community, school is seen primarily as the site of acquiring English. Many participants expressed the difficulty they experienced learning English. Naomi, a green house owner, remembered the difficulty she had learning English at the pace expected by the teacher. She said, "it wasn't ever easy for me." Similarly, Caleb, a blacksmith, told me that he felt "pressured to learn a lot of English very quickly," and that he didn't like learning under what he saw as stressful circumstances. Both Naomi and Caleb asserted, though, that it was the older students at school who helped them finally learn to speak and understand their new language. While a few participants also praised especially patient teachers, almost everyone said that the biggest source of help they had in acquiring English was from older students in their classes. Sometimes, the older students were siblings. Matthew, a bishop of the community, remembered that his teacher at the private, Amish school he attended explicitly asked his siblings to speak English to him at home, despite the fact that Pennsylvania Dutch is the language of home life. At other times, though, students do not have the advantage of learning from their siblings. David, a nine year-old boy, told me that he knew most of the English he knows because of the older kids at school. He is the oldest child in his family, so he only learns from other school friends. He explained:

David: I'm the oldest, and I probably would have known more about how to speak English when I went to school if I had a big brother or sister. 
TA: Who taught you to speak English so well?

David: My teacher. And the kids at school help me.

But even when students did go to school with the advantage of knowing some English, they credited older students for their success in school. Grace, a young woman known for helping elderly people in the community, said "my parents always read books to me in English, and then they'd translate the meaning into Pennsylvania Dutch." She cited this activity as being one way in which she learned to speak English and felt this gave her an advantage going to school, but she still asserted that most of her English language learning came from hearing the older students at school speak English.

While teachers cannot mandate that students help one another with English acquisition at home, they can and do enforce English use at school. Jacob, an Amish man who invited me to meet his children and sit at their kitchen table, recalled: "my teacher made us speak English. Even during free time. We were only allowed to speak Pennsylvania Dutch during the noon hour recess. We had to speak English during our other two recesses, and we always used English in the classroom." This noon recess retreat to Pennsylvania Dutch, however, would be seen by many Amish students as a rare treat. Many interview participants stated that this luxury was not allowed at their school. Faith, an early settler to the community, said that her teacher enforced English even on the playground. Some teachers use playtime as an incentive for speaking English. Several participants stated that their teachers threatened to take away their recess time if they didn't use English. Caleb said he was "hesitant" to learn English, and he only cooperated with the teacher when it came to English language learning after she threatened to revoke his recess rights. Free time, however, is seen by some teachers as an 
opportunity for students to use their new language skills while at play. Many participants said that when they reached the higher grades, they were expected to play with the younger children at recess, not only because this was seen, as Daniel, a former Amish and now Mennonite man said, as "the Christian thing to do," but also because this exposed new English users to more experienced speakers of English.

The theme of learning from older students was found so often in the interviews that I asked a local Amish school teacher, Hannah, if she encourages students to collaborate in her own classroom. Hannah said she regularly relies on the older kids quite often to help the younger kids learn English. She said:

I expect the older kids to play with the younger kids on the playground. After playtime is over, the children come back into the classroom and I read a story in English. I don't translate the story. If the younger students do not understand, they ask the older students for help, and the older students do not mind to help the younger students because older students had helped them just a year or two earlier.

In reading instruction, Hannah works individually with students or puts students into groups based upon their current reading level. Since the classroom is made up of students in grades one through eight, there are generally six or seven different reading levels in the classroom at any time. At Hannah's school, there are typically fifteen to twenty students in school each year, and as a result, students can always find someone with whom they can read if the teacher is working with another student. Hannah said that collaboration and group work are important elements in all of her teaching, but she relies on these techniques especially when it comes to reading. Brandt's concept of sponsors of 
literacy is useful in understanding why this model works so well for Amish schools. Brandt says that sponsors of literacy are "any agents, local or distant, concrete or abstract, who enable, support, teach, model, as well as recruit, regulate, suppress, or withhold literacy — and gain advantage by it in some way" ("Sponsors of Literacy" 556). In the Amish parochial school model, children gain advantage only by winning approval from their parents, teachers, and peers by sponsoring one another's literacy and language development. But Brandt also says that "obligations toward one's sponsors run deep, affecting why, what, and how people write and read" (558). The Amish model complicates this claim because while students do feel obligations or gratitude toward their sponsors, becoming a sponsor also carries its own weight of obligation. Hannah said that she expects the older students to help the younger students, and this exchange is based on what I call a "pay it forward" model of literacy learning, a model where students do a good deed - help younger students learn to speak, read, and write Englishin order to "pay" for good deeds from which they benefited.

I asked Hannah why she asks students to help one another, and she answered thusly: “That's how I was taught. That's how we learn. And the students like helping each other. Our religion teaches us to help one another, so that is what we do in school." Aside from following the teachings of her religion and traditions of her own education, Hannah is engaging in good pedagogical practices that are supported by our own discipline. In rhetoric and composition, the practice of using collaboration in the classroom is grounded in arguments made by Kenneth Bruffee in Collaborative Learning: Higher Education, Interdependence, and the Authority of Knowledge. Bruffee argued that as college students are entering new conversations and scholarly 
communities, social interaction is the best way to gain entrance into these conversations, and this entrance can be attained only by allowing to students to work together. In the Amish model, students are entering an exclusively English speaking community for the first time, and interactions with English speaking peers can help them acculturate to their new speaking community.

While this model of collaboration may be found in non-Amish schools as well, what I see as being exceptional here is that the Amish students come to expect this practice. Hannah reports that her students rely on one another perhaps even more than they rely on her. In return, as the younger students age and become the older students, they are expected to volunteer to help the younger students, just as they had been helped, again, to "pay it forward." We must remember, too, that while the older students are more experienced English speakers than the younger students, they are still learning, too. This model also reflects Bruffee's arguments about collaboration in "The Brooklyn Plan: Attaining Intellectual Growth through Peer-Group Tutoring." Just as the more experienced tutors gain knowledge from working with peers in Bruffee's writing center model, the more experienced English speakers in Amish schools improve their English literacy by helping their younger classmates learn to speak, read, and write English. One may also understand this concept through Lev Vygotsky's concept of the zone of proximal development. Vygotsky cites Dorthea McCarthy's study in which "[w]hat her subjects could do only under guidance, in collaboration, and in groups at the age of threeto-five years they could do independently when they reached the age of five-to-seven years" (87). Vygotsky points to this result as an example of the importance "of the role of imitation in learning" (87). The Amish model, then, makes use of this same method; 
younger students imitate older students until they reach the developmental maturity to read, write, and speak their new language.

Collaboration as a model for education goes beyond the classroom experience. Amish education is seen as a collaborative effort between parents and the teacher. First, as Hannah tells me, the teacher is chosen by an elected body that is part of the church district board. This board consists of three couples in the community, and these three couples decide together who they will ask to be the school teacher. Hannah described how she became a teacher thusly:

- Hannah: Some of the board members for the school came to my house. They asked my mom and dad if I was home and if they could talk to me. I came in from working outside and they asked if I would be interested in being a teacher for the school. And, so I became the teacher.

TA: Did you want to be a teacher when you were a little girl?

Hannah: No, not that I remember.

TA: Were you a good student when you were in school?

Hannah: I guess so?

TA: Did you like going to school? What was your favorite subject?

Hannah: Yes, I enjoyed school. I liked vocabulary the best. I also liked it when our teacher read the Bible to us in German on Friday afternoons.

TA: Why do you think you were asked to be a teacher?

Hannah: My uncle is on the board, so he knows me and my family. He knows that I like the children and that the children listen to me. I guess they ask people 
who can work with the children, and they want people who everyone knows. I guess people know my family.

Hannah's modest explanation of how she came to be a teacher matched up with Stephen Bowers Harroff's description in The Amish Schools of Indiana: Faith in Education. Harroff says:

The Amish still treat teaching like a calling; that is to say, one does not train to become a certified, credentialed teacher, and then go looking for a teacher job. Instead, a member of the school board usually comes to one's home and asks if one would consider taking up the calling of teacher, at such and such school, for the next term (school year). And this visit is made only after much discussion among the school board and church officials about the Christian character and suitability of the person, including their ability to maintain discipline and to handle the subject matter. (58)

The teacher is typically a young —often only a few years older than the oldest students, as Harroff points out-unmarried woman from a respected family in the community, and Hannah is no exception.

In addition to the collaborative effort toward choosing a teacher, collaboration between parents and the teacher is expected. Harroff notes that parents are welcome guests at Amish schools and that most Amish teachers "say they wish they would have more visitors at school" (160). Hannah sees what occurs in her classroom as a collaboration between herself and the parents' of her students. She meets with students' parents regularly to discuss individual progress. Hannah notes that these meetings are 
facilitated by written notes and records she keeps on each student detailing progress, grades, and behavior. If the student is performing unfavorably, she works with the parents to create a plan to help the student's grades or behavior improve. Amish schools, too, hold PTA meetings on a regular basis. Again, non-Amish schools also have PTA meetings, and many public school teachers also see education as a collaboration between parents and teachers. Shirley Brice Heath, for example, discusses at length the personal responsibility parents feel toward their children's schools in Ways With Words:

Language, Life, and Work in Communities and Classrooms. However, the collaboration present in Amish schools goes beyond the engagement of teacher and parents. Amish schools are only successful if the collaborative effort is made by the entire church district.

The amount of time, services, and money that Amish community members invest into their schools far exceeds the investment a typical American makes into her own community schools, such as paying taxes. ${ }^{7}$ In Hanley, children attend schools founded, supported, and maintained by the Amish church district. The success of the school is every Amish church member's responsibility, not only the parents'. As Harroff states, "as the school is the only building that an Amish community erects and supports with its time and money, the school occupies a central position in the community and is the focal point of many community events" (150). One of these events is the annual auction where church members donate items for sale like quilts, furniture, and baked goods. The auction is coordinated by an elected committee, and more often than not, the members of

\footnotetext{
${ }^{7}$ I acknowledge that Catholic parochial schools and families who homeschool their children also invest this kind of time, services, and money to their childrens' education. What is distinctive here is that the Amish do so in interest of staying separate from society in order to preserve both their faith and their heritage.
} 
this committee do not have children currently enrolled in school. In fact, this year's committee in Hanley is directed by Adam and Eden, a couple who is known throughout the community for not being able to have children. In addition, most of the items donated to the auction come from families whose children are now adult-aged, and the amount of time and resources that go into the creation of these donated items, and especially into items like quilts and furniture, cannot be overstated. Matthew told me that "community members who no longer have children in school are usually in a better position financially to donate items to the auction, and so the responsibility to support the school is shared by everyone." As I saw for myself when I attended this year's auction in Hanley, the auction is consistently well attended, both by Amish and English people (or, as the Amish call us, Englischer), and the event raises enough money for the four Amish schools in Hanley to operate comfortably for an entire year.

But not every Amish child is educated in a private, Amish setting. Sometimes, Amish children attend public, state funded schools. A good portion of the participants in this study attended public schools for some if not all of their education. Daniel, who was raised Amish but is now Mennonite, says that in communities where there is a large Amish population, Amish families and church districts often decide against building and sponsoring a private Amish school and send children instead to public school, arguing that there is, as he put it, "safety in numbers" for groups of Amish children who attend school together. Daniel said that his class in school was made up of "approximately forty to fifty percent Amish children," and the public school district accommodated Amish faith and customs by teaching the children to speak English—often with the help of other students in the class, as is the custom with private Amish schools - and by allowing 
Amish students to attend only through eighth grade without penalty to the student or parents. The Amish parents in Daniel's county, Holmes, Ohio, negotiated with the Ohio state school board for this arrangement, as his time in grade school pre-dated the 1972 Supreme Court case Wisconsin V. Yoder. ${ }^{8}$

In cases where the Amish church district does not sponsor a school where German instruction occurs, the community often engages in students' education in a different way. ${ }^{9}$ When Daniel was a child, his local church district taught German to Amish children and anyone else who wanted to learn it in the "off Sunday," an expression I have heard used to refer to the Sunday opposite of when church is held. ${ }^{10}$ He said:

We had to study German at church so that we could read the Bible and understand the sermons and songs. Since we weren't going to an Amish private school, the church really had to teach us. In that way, the church district worked with the schools to educate all of the children.

Even though Amish children in Hanley attend private schools, the church districts also participate in children's education outside of the classroom. Luke, a bishop in the community, said "the church started sponsoring a German spelling bee every few months

${ }^{8}$ See Hostetler and Huntington for more discussion of the tumultuous battle for Amish parents' rights to educate their own children in Ohio.

${ }^{9}$ As I'll discuss in chapter three, Amish schools all observe the practice of studying Old German on Friday afternoons.

${ }^{10}$ Amish church districts, or gmas as they're referred to in Amish German, hold church services every other Sunday. Typically, as is the case in Hanley, two local church districts coordinate schedules so that they do not meet on the same Sunday. This way, if neighbors want to attend church on both Sundays, they have the option to do so, although most people in Hanley use the "off Sunday" as an opportunity to visit friends and family. The fact that these two districts coordinate their schedules is further evidence of collaboration between the two districts. 
so that the children can improve their German vocabulary. Old German is important for our religious practices." I discuss the uses of Old German more in chapter three.

The model of collaboration found in formal education is reflected in other Amish institutions. For example, even though all Amish men (and some women) take on a trade like farming, woodworking, or blacksmith forging to support themselves and their families, there is no formal training for these trades. Instead, Amish business owners take on apprentices and train them individually in their chosen trade. This model, which is seen as being beneficial to both the apprentice and the employer, illustrates the necessity of collaboration for Amish survival. In a community where high school, trade school, technical school, and college are not options, the Amish must depend on one another to acquire profitable skills. The only way in which these skills can be acquired, then, is for experienced workers to train the inexperienced, thus mirroring the model of those with knowledge helping those without which the Amish learn in school.

Amish church, too, is a site of collaboration in the Amish community. Church services are held in a different parishioner's home each week, and the young men of the church come to this family's home late on Saturday evening with the "bench wagon" to set up and arrange the long wooden benches where the church members will sit.

Collaboration is also found in the hierarchy of the church districts. Each church has four ministers: two who are deacons, one who is a bishop, and one who is a minister. While there is a chain of command-the bishop is the leader, then come the deacons, then the minister - the church leadership makes decisions together and even delegate important tasks to committees. The church also works with members of other church districts. Matthew, one of the two bishops I interviewed, said that whenever the community has a 
visitor who is a minister, they invite him to give the week's sermon. This practice shows that the church districts, while they may be governed by different rules (called Ordnungs by the Amish), can still cooperate and work together.

In this section, I have shown how collaboration is used as a model for Amish institutions like school, the school board hierarchy, trade training, and church. In the next section, I will illustrate how collaboration with English neighbors, friends, and business people provides a primary site of English language acquisition for many Amish people.

\section{“That Boy of Yours Understands English": English Learning Language as an Act of Collaborating and Working With Outsiders}

In Amish Literacy: What and How It Means, a 1988 study of one Amish family's literacy practices, Andrea Fishman argues that the fact that the Amish speak English at all is evidence of their collaborative spirit. She asserts:

While reading English at all is a cooperative act, conducting school in English, as required by [the 1973] Standards [of the Old Order Amish and Old Order Mennonite Parochial and Vocational Schools of Pennsylvania], overtly acknowledges the need for such cooperation. Conducting written business in English also facilitates cooperation and, thereby, survival. [...] Teaching English as a school subject and writing school assignments in English prepare students to cooperate with the English world as adults, so the schools created to reinforce separation and to promote affiliation and identification contribute significantly to cooperation as well. (147) 
Indeed, I found that my interview participants saw English as a necessity for cooperating with those who are outsiders to the Amish community. In addition to learning English in order to work with English people, I learned in the interviews that the act of learning English was often credited to interactions with English people, especially in Amish businesses. Seven interview participants-Ruth, Jacob, Bethany, Esther, Ezekiel, Faith, and Naomi-explicitly referred to English as "the language for business."

When collecting interviews for this study, I visited many interview participants at their places of business. These businesses include a furniture varnishing shop, two shops where furniture is made, a green house, a blacksmith's forge, a dry goods store, a shop where playground equipment is made, a farm, and a store where jelly is sold. ${ }^{11}$ These businesses serve both Amish and English patrons in the greater Hanley area and are typically quite profitable for the business owners. Usually the business is the primary concern of the husband, but there are exceptions. The greenhouse I visited is owned and run by Naomi, while her husband grows vegetables nearby. The dry foods store is cared for by Bethany, and her husband works primarily as a farmer. The jelly store is owned by Anna whose husband builds playground equipment in his shop on the other side of their yard.

Many interview participants listed their parents' shops as the initial site for hearing and learning English. Ezekiel, a furniture varnishing shop owner, said "my dad owned a shop with a lot of English customers, so we heard English all the time. I didn't know a lot of English when I went to school, but I did learn some from dad's English

\footnotetext{
${ }^{11}$ The Amish in Hanley usually refer to their businesses as their "shops," and these shops are usually located on the same property as their homes. Typically, the shops are built with the same materials as the home, so shops and homes typically match or look alike.
} 
customers." Similarly, Jewel reported: “my parents worked for an English family, so I knew a lot of English when I went to school. Maybe that's why English spelling was my favorite subject." Amish adults who were not exposed to many English people during childhood say they knew little to no English before going to school. Abigail said her parents lived far away from any English people and were farmers, not shopkeepers, which kept the family isolated from English patrons. But this trend of being isolated from English speakers as a result of farming is declining. Luke, the community Bishop who showed concern for this subject, said that when he was a child, approximately ninety percent of the Amish families living in Holmes County, Ohio were farmers. ${ }^{12}$ A recent census, he said, found that currently only seven percent of families in Holmes County own farms, which means that most Amish families now own shops that serve English customers or work for English employers. ${ }^{13}$ The result of this, Luke believes, as do others I interviewed, is that "English is becoming more dominant in the minds of the Amish," and Pennsylvania Dutch and Old German are slowly slipping away. In chapter three I discuss further the future of Pennsylvania Dutch and the increasingly important placement of the English language in Amish life.

Amish businesses are not the only sites of collaboration between English and Amish people to which my study participants attributed their language acquisition.

\footnotetext{
${ }^{12}$ Holmes County, Ohio, is home to the largest Amish population in the world ("Amish Country, Ohio."). Most of the Amish currently living in Hanley originate from Holmes County and still have family members living there. This fact, paired with the concentrated population of Amish living in Holmes County, often leads to Holmes County being held as an Amish standard.

${ }^{13}$ This decrease in farming families in Holmes County correlates with the USDA's reports of decreasing family farms. According to their most recent reports, the number of small family farms operating in the United States fell by over 61,000 between 1983 and 2003.
} 
Often, Amish children learn English words by witnessing the interactions their parents have with their English friends. David, a nine year-old boy, said that he learned to understand English by listening to his father talk to English people. His father, Jacob, told me: "about five years ago, one of my friends and I were talking to your future father-in-law, and David was there with us. My friend said 'that boy of yours understands English! I can tell by the faces he makes."' When I asked why he thought it was important to learn English, David said that it was so he could "work with English people like you and be a good neighbor." This, I believe, illustrates that Amish children are taught to be conscious of their English neighbors and that English people can make good friends.

This consciousness of English neighbors embodies itself in interesting ways. Several participants mentioned in their interviews how incredibly rude they felt it was to speak Pennsylvania Dutch in front of English speaking people. Naomi mentioned one English woman in particular who often drove a van for the Amish community members going on long trips, typically to Holmes County. This woman complained when they spoke Pennsylvania Dutch, and, as a result, the people in the community made a more concerted effort to use English around her. Naomi seemed very distressed that she had offended this woman with her native language, but was delighted to find that the van driver had learned some Pennsylvania Dutch words from listening to her and her friends speak to one another. She said: “I'm really happy when my friends pick up Dutch words from me. I like feeling like I taught them something." Similarly, Samuel, a Mennonite man who earns his living by repairing small motors, said he heard one of his English friends use the word spritzen, a Pennsylvania Dutch word that means "the sky is 
sprinkling rain." Samuel saw this as evidence of the two cultures—that which revolves around English and that which revolves around Pennsylvania Dutch—“coming together." Samuel told this story with a great deal of happiness. He, like Naomi, liked the fact that his English friend had learned a Pennsylvania Dutch word from him but was worried that he had been rude and had spoken his home language in front of English speakers too often.

Other participants who see it as a rude act to speak Pennsylvania Dutch in front of English speakers compare this act to those of immigrants who, as they see it, should speak English in the United States. Eden, a woman who raises sheep, recalled a summer when she worked as a strawberry picker with Mexicans who spoke Spanish exclusively. She said, "I thought it was really rude that they spoke Spanish in front of me. They knew I couldn't speak Spanish. It made me really uncomfortable. I always wondered if they were talking about me." I heard similar stories from other participants when I asked them why they thought it was important to speak and understand English. Immigrant groups and especially Mexican immigrants were mentioned by several participants who saw English speaking and understanding as a necessity of living in the United States. Naomi says she had to learn English "in order to get along." She continued, "without English, I'd be handicapped! What would we do when we went to Wal*Mart?!" This sentiment was repeated by Abigail who also used the word "handicapped" to describe how she'd feel without knowledge of English. Joel, one of the early settlers of Hanley, says he "wouldn't get too far" without knowing the English language. Bethany, the woman who owns and runs a dry goods store, cited communication with customers as an important reason to learn English, but she also included "being neighborly with you [English] 
people" as a good reason. And perhaps most illustrative of the English imperative, Caleb, a blacksmith who considers himself a history buff, said that English is necessary "to exist in the United States." These kinds of comments-especially pointing specifically to how they Amish would be treated at Wal-Mart if they did not speak English-point to the material value of English (Stuckey; Brandt) and will be discussed in more detail in chapter three.

This desire to speak English well in order to communicate with English people in the United States is more dominant, though, in the Mennonite community than in the Amish community. Unlike the Old Order Amish, the faith and denomination of most of the participants in this study, Mennonites are evangelical and seek to bring English people to their faith through service and missions. Therefore, as Daniel explained, "it benefits the Mennonite church members to speak English not only well but also without an accent in order to attract English speaking new members." Also, Anna reminded me that "learning to be Mennonite is difficult enough without adding the learning of a new language" to learning the restrictions on lifestyle, dress, and behavior. Therefore, as I will discuss in chapter three, many Mennonite church districts no longer teach Pennsylvania Dutch to their children and are leaving this language behind for good in the name of evangelism.

In this section, I have shown how collaboration with English people works not only as a site for English language acquisition but also creates a mandate for English. The next section shows how the international Anabaptist newspaper, The Budget, which I discuss in more detail in chapter four, further demonstrates the Amish collaborative literacy model. 


\section{“Careful What You Say to Samuel; He's a Budget Scribe!": Collaborative Publication and The Budget Newspaper}

As I discussed in the first chapter, The Budget, the primary source of Amish and Mennonite news, is made up of letters written by scribes who either volunteer or are assigned the job by church leaders. The role of the scribes is very important and, as I will discuss in chapter four, is seen as a position that deserves respect in the community. As Luke, a scribe himself, put it, "The Budget doesn't exist without its writers." I interviewed three current scribes and one former scribe for this project. The most common thread I found in the scribe interviews, however, is that the scribes take their positions very seriously, see themselves as voices for the entire community, and consider their service to The Budget as a service to both church and community.

The first scribe I interviewed was Samuel, a Mennonite man who, because the Mennonite church allows for the use of technology and modern conveniences, composes his weekly Budget letters with a laptop computer and then faxes those letters to the Budget's main office in Sugar Creek, Ohio. Samuel, unlike the other scribes I interviewed, writes for The Budget every week. He says that he writes the letters and his wife, Lydia, proofreads them. Samuel does not see proofreading as any less an act of authorship than the invention and composing in which he engages, so the letter is always signed by both him and by his wife. He said "I sign the letter with my name and Lydia's because we're both the authors. She does her part by editing my work." He says that Lydia also contributes to the letters in that she helps him gather and remember the important information that should be included in his weekly letter. While Lydia did not 
seem to be too interested in any discussion of The Budget and even left the room during my interview with Samuel, Samuel sees her role in the composing of their weekly letter to be as important as his, and therefore, he sees their scribal responsibilities as being a collaborative effort. Samuel's willingness to share authorship with his wife in order to credit her for her efforts is contradictory to the arguments about the "prestige of authorship" made by scholars like Deborah Brandt; Brandt argues that this prestige is given away in ghostwriting exchanges ("Who's the President?"). While it is true that the position of Budget scribe carries prestige in the community, Samuel is willing to share that prestige with his wife, despite the fact that the responsibility was given solely to him.

I found collaboration between husband and wife again between Ruby and Luke. Ruby was an Amish Budget scribe for thirteen years. As she got older, she developed health problems and could not continue the duty. Her husband, Luke, did not want the job to go unfinished and has covered the biweekly duties for the last two years, albeit reluctantly. He says he feels "like a substitute," though, and that the job is really Ruby's. While he does not enjoy this chore, he thinks it is important and does not want to delegate the task to another family because he sees it as a responsibility to his community and his church. Luke, unlike Samuel, signs the letters with his own name, and when Ruby was the scribe, she only signed her own name. So while Luke and Ruby see the task as a responsibility that belongs to their family, they do not share the writing process in the way Samuel and Lydia do.

Joseph, a scribe who writes biweekly on his own, asserted that he saw his responsibility as a Budget scribe to be the "mouthpiece" of the community. He says that he tries to write news that "people will be interested in." Joseph acquires his Budget 
content from talking to people, from hearing people talk at church, and by "keeping [his] ears open" for what should be in the Budget. He adds, "I hardly write about my family or my parents. I do sometimes, but I don't like to, I like to write about other people." Similarly, Samuel said it is important to him that his audience doesn't feel like he's writing about himself. He takes his job as representing the community-not just his family-very seriously.

The responsibility of being a Budget scribe, as I have stated, is one that is respected throughout the community. The responsibility is seen as being so important that the church hierarchy ensures that someone is in charge of this important task at all times. Samuel, the Mennonite scribe, notes that Amish and Mennonite church districts typically appoint a scribe for a specified length of time. Because of the nature of their work, reporting church news like service locations, baptisms, marriages, and births, the scribe is seen by the Budget's reading audience as a representative of the entire church district. Samuel was asked by his church leaders to be a scribe over ten years ago. Joseph, an Amish woodworker, has been a Budget scribe for two years. He, too, was asked by his Bishop, Matthew, to be the scribe for his area. Luke, a scribe and Bishop, began covering his district three years ago when his wife Ruby's health problems began to interfere with The Budget scribe duties she had carried for thirteen years. Ruby became a scribe sixteen years ago when she and her family moved to Hanley. She voluntarily took on the scribe duties because there was no one writing from her area. All of the scribes note that they see their Budget duties, whether they enjoy the task or not, as being a service to the church and community: the two bodies that are at the center of Amish life. 
I see The Budget as being a uniquely Amish text. As I'll argue in chapter four, the Amish are using an old technology to create an international sense of community among Anabaptist people, and while non-Amish readers and writers use newer technologies like blogs, e-mail, and the telephone to create community, the individual participation from community scribes and the sense of responsibility with which scribes approach their writing reveals a lot about Amish values. In early conversations with community leaders, however, I found it difficult to articulate to them exactly why The Budget is so special and interesting. In an effort to show how unique The Budget is to scholars of rhetoric and composition, I asked six graduate students in a rhetoric and composition $\mathrm{Ph} . \mathrm{D}$. program to read random selections from The Budget and then list words and phrases to describe what they had read. The phrases used most often by the graduate students were "community minded," "to an audience with whom the writer is familiar," "friendly," and "detailed." I asked each of the scribes - both current and former-if they thought these were fair descriptions of the content of The Budget. Each of them agreed that, indeed, these phrases were good descriptions of the paper. The phrase that seemed to stand out most to the scribes was "community minded." Luke argues that scribes "must be community minded... why else would they write?" A good scribe, they each said, writes about the community and not about his or herself. In order to get news for The Budget, then, writers must be good neighbors. Samuel reported that he tries to engage neighbors in simple conversation without seeming like he is "being nosey for the sake of The Budget," but that he is always "on the look out" for Budget material. He has even heard some people say, "Be careful what you say to Samuel, he's a Budget scribe!" He does have some friends, too, whom he can call and ask if they have 
any Budget news. Luke covers two of the four church districts in his area. His neighbor who attends another church district keeps track of the news from her district for him. Caleb, who is not a scribe but a long-time reader of The Budget, said that the Budget began as a newsletter used for "communication between communities and people," and explained that the community-minded letters written by scribes were a result of the origin of the paper.

The fact that The Budget letters are meant to represent an entire community highlights the importance of community in Amish and Mennonite life. Daniel, a former Amish man who is now a Mennonite, said that he sees community as being at the center of Anabaptist life. In fact, Fishman argues that community is at the center of Amish life. Preserving the community is important, as is appropriately representing the community in texts like The Budget, and reading this text is important to staying connected with the larger Anabaptist community. As a result of this need to be connected to the larger community, Luke emphasized the importance of Budget scribes in new communities. His wife Ruby, too, said that she started writing as a Budget scribe because newer communities "need scribes to connect them with the older communities." Indeed, when I asked interview participants how they decided which letters to read in The Budget, many said they started with letters from communities where they or their parents had once lived. My readers can imagine how important this once-a-week connection is to a community who cannot rely on telephones, e-mail, or blogs for updates on their loved ones' lives. While almost everyone I interviewed writes and receives letters from family and friends on a weekly or bi-weekly basis, The Budget is a just as important news 
source. To emphasize this point, Hope told me: "I didn't know my sister had a baby until I read it in The Budget."

During the interviews, Budget scribes also focused on the elements of their letters that make them seem as though they were writing to an audience with whom they were familiar. When asked to visualize his audience, Luke said "I think about my parents when I write. I pretend I'm writing a letter to them that I'm letting everybody read." He added that his parents like that he is a Budget scribe because he never writes them personal letters, but emphasized the importance of making sure the letter was not "all about us"meaning himself and his family — and instead covers the goings-on of the entire community. Joseph said, too, that he thinks about his parents when he writes his letters, but that he tries to not write about himself, not only because that's not what people want to read, but also because it's "nobody's business." Samuel emphasized the importance of writing about people in a way "you'd want someone to write about you." He claimed that he never writes anything in The Budget he wouldn't want written about himself or his family. All three scribes said that while they are careful to write about the community in a positive way and even added that the editors of the Budget do not allow scribes to speak negatively about someone, they often think of their public Budget letters as substitutions for personal letters.

But personal letter writing, like Budget letter writing, is seen by many of the participants as a collaborative, family act. Several of the women I interviewed stated that they wrote letters to friends and family that were intended to be from the entire family, not only from the writer herself. In other words, these women often write a letter to their parents but sign their husband's and children's names in addition to their own. Bethany 
reported that she writes at least one letter per week to her family and friends in different areas. Her husband, too, writes letters regularly, but she concedes that "yes, women usually do the writing for the whole family." When I did encounter families where the women write for the family, the men and children usually contribute ideas to be included in the letter. Hope, who received two personal letters during our interview, said that she corresponds with her family and her husband's family, otherwise "they get worried" about their well-being. When I asked her husband, Jacob, why he does not write to his own family, he said he does not enjoy writing and that Hope "does a good job." Clearly, gender roles are at work in the literacy practices of this community. While some women do write for The Budget, the three scribes who represent the Hanley area are currently all male, with the slight exception of Samuel and Lydia who are both listed as authors, although Samuel is responsible for all the writing except the proofreading and revision. One may argue that Samuel does the intellectual work of writing while Lydia is responsible for the "editorial labor." This trend-found only in the public writing of this Amish community-reflects the convention Kara Poe Alexander and Joanna Wolfe found in collaborative writing groups where women act as the group "scribe" or "secretary" while men take leadership positions. Keeping in mind that Samuel and Lydia, as Mennonites, are far less conservative than their Amish neighbors in the community, one must also wonder how often women engage in the editorial labor for their husbands' Budget letters without receiving credit for their work. I observed that, with exceptions, women are primarily responsible for private writing — family letter writing, for example-while men in the community engage in public writing, such as letter writing for The Budget, letters to neighbors advertising the annual auction, and writing for 
business transactions. But the public element of men's writing in the community may contribute to the fact that the men I spoke with enjoyed the act of writing far less the women I interviewed. Overall, it seemed that the women interviewed for this study reported that they enjoyed writing more often than the men I interviewed. Of the 13 women I interviewed, 11 listed reading, writing, and spelling as favorite subjects in school, while only two listed mathematics or science. Of the men, only four listed writing, writing, and spelling as favorite subjects, while five listed science or math, two listed history, and one (Caleb) claimed that he did not enjoy any subjects at school.

The sense of responsibility that comes with public writing, as I have argued, is especially clear in the writing of letters for The Budget. Not only do scribes want to write letters that have the content readers "are looking for," but they also want to represent their communities "fairly." And as I will argue in chapter four, scribes are careful about how they represent their communities, much like an advocate or anthropologist who is writing on behalf of a community. Because scribes seem so aware of their audience and how they want to present themselves and the community to readers, I asked scribes and readers alike about how they wanted their community to be seen by readers in other Amish communities. Samuel, a scribe, said that he hoped readers of his Budget letters would get the sense that his community is "open, friendly, and active." He added that he enjoys traveling to other areas and meeting people who read and enjoy his letters. Samuel is so concerned about the quality of his Budget letters that he asked me, "as a writing teacher, what would you say about my letters?" I told him that I loved reading his letters and especially liked reading his descriptions of the weather in Hanley. Abigail, a reader, said that she hoped her community as portrayed by Luke, the bishop scribe, 
would be seen as friendly. Matthew, anothers bishop, was not surprised that the scribes want the community to be seen as friendly because he sees the friendly tone in The Budget as a manifestation of Christianity in the daily lives of Amish and Mennonites who write for The Budget. Former scribe Ruby said that she also wants people to think the community is friendly, but more specifically, when she wrote for The Budget, she wanted to represent the community as one that "worked together and had a sense of humor" about itself. She mentioned several times that she liked writing about funny events and enjoyed reading other scribes' funny stories. But not everyone shared this sentiment about humor. Her husband, Luke, who is now covering the district's news, claimed that he never tries to be funny in his letters. And Adam, a reader, asserted that The Budget is not for entertainment, and instead, he sees it as "an important news source." He says that Budget scribes write "what people are looking for."

Something that readers seem to be "looking for" in The Budget are ways in which they can help their neighbors. Female participants, in particular, talked a lot about looking for "showers" in the The Budget. Showers are calls for sending money or items to people who need them, either to pay medical bills or to recover after some kind of tragedy. Sometimes showers are just calls for cards of encouragement to people who need uplifting. Showers are not permitted in regular letters and The Budget charges for printing shower announcements. Faith, one of my participants who said she looks for these first, sees announcements of showers as an important element of The Budget because it gives "all readers an opportunity to help" the larger Amish community. Former scribe Ruby said that she, too, looks for showers first, and sees this as part of how The Budget forms community among its readers. I see showers as further evidence that 
Amish community members can rely on one another in times of need, and the fact that the women I interviewed seek these announcements out on a weekly basis shows that this collaborative spirit of community well-being is thriving in Hanley.

In this chapter, I argued that the Amish and Mennonite emphasis on community and tradition of collaboration are reflected in the literacy practices of Amish and Mennonite people living in Hanley. Education, both at pedagogical and organizational levels, is collaborative. Students are taught to help one another, and the success of students is of concern for the entire community, not only the students and their parents. The way in which the English language is acquired is often the result of exposure to English speaking people, and the value in learning English is based in being neighborly to English speaking people. The Budget would not exist in its current form if it were not for scribes taking care to cover community news, and community news collection is often a collaborative effort among spouses, neighbors, or church communities. Indeed, The Budget would not have a reading audience if it were not for the Amish and Mennonite value of concern for the Anabaptist community as a whole. In short, these literacy practices are shaped by values revered in the Amish community: collaboration and preservation of community. In the next chapter, I will show how the languages of Amish people-Pennsylvania Dutch, English, and Old German-have been delegated to separate spheres of life, and I will argue that despite the focus on community preservation, the necessities of Amish life in the modern world and the normalizing effect of English literacy in the United States have put the home language of the AmishPennsylvania Dutch — in danger of becoming defunct. 


\section{CHAPTER THREE}

\section{"THE LANGUAGE ON THE TIP OF MY TONGUE": THE ROLES AND SPHERES OF PENNSYLVANIA DUTCH, ENGLISH, AND AMISH GERMAN}

Amish communities typically use three languages: Pennsylvania Dutch, English, and Old German. The purpose of each language, which I will describe in this chapter, is specific and universal across the community. Languages in the Amish community, then, exist within specified spheres of Amish life, and these spheres rarely overlap. In this chapter, I introduce the purposes of each language and show how this segmentation of language has affected literacy in the Amish community. Through this analysis, I argue that English literacy has acted as a normalizing agent (Goody; Goody and Watt) upon the Amish despite the community's historic attempts to avoid assimilation and show how Amish language traditions, like literacy practices, have been informed by the values of the community.

Before beginning this analysis, I want to clarify that I do not take literacy and orality to be the same. As I explain in chapter one, I follow in the tradition of literacy scholars such as Deborah Brandt, Mary Barton and David Hamilton, Shirley Brice Heath, and Brian Street and base my argument on the idea that literacy is the practice and ability to produce and interpret symbols toward the ends of communication. Conversely, as 
Ong, Brandt, Robert Yagelski, and Sylvia Scribner and Michael Cole argue, orality is the verbal expression of thought. I do not conflate the concepts of literacy and orality but instead argue that the dominant, normalizing effect of literacy as described by Goody and Watt affects all facets of life, and in this case, the brunt of this change can be observed in the oral practices of the Amish community.

In order to understand the purposes of language in the Amish community, I began each interview by asking participants to answer the same question: "Will you tell me about the languages you use?" Participants reported the Amish community uses three languages and the purposes are specified by Amish faith. Bethany, a shopkeeper, eloquently explained these purposes as follows: "We use English to communicate with English neighbors and for business transactions; the Pennsylvania Dutch is for home and connects us to our forefathers; and we use German at church." To Bethany and others who participated in this study, ideas about language use are utilitarian. This attitude was reflected in the responses I received whenever I asked participants about the benefits of speaking two or more languages. Matthew, a community bishop, said it was only good to know two languages if you were going to use both languages. He said "if you don't use it, you lose it" and compared the practice required to maintain a language to the fact that one must practice arithmetic in order to remember how to do complicated operations like fractions. This "use it or lose it" attitude was found again during my conversation with Naomi, a greenhouse owner. When our interview was over, she asked if I knew any languages other than English. I said I had studied Spanish in high school and college but do not really remember much of the language now. She said, sadly, "Yes, you have to use a language in order to keep it." 
In getting to know a large number of Amish people living in Hanley, I have come to see these kinds of statements about the usefulness of language as an attempt to show that their multilingual nature is not motivated by pride or an effort to seem smarter than English speakers. Several participants were careful to not seem as though they were bragging, which in hindsight may have been in response to my descriptions of the multiligualism of the Amish as "special" and as something from which "we in the university could learn." The bishop, Matthew, specifically asked my informant, Rebekah, after the interview if she felt he had disobeyed the rules given to Christians in the sixth chapter of Matthew, which orders Christians to avoid being judgmental or proud. In later interviews, I abandoned questions that portrayed Amish literacy practices as unique or special. Instead, I asked participants to verify facts I had learned in previous interviews and to confirm if their experiences were similar. Although this technique typically led to more comfortable interviews, participants continued to emphasize the utilitarian nature of their languages and were eager to explain why all these languages belonged in Amish life. This chapter, then, will focus on how each language is used by the Amish community, how these uses reflect Amish values, and how this segmentation of languages has affected the community. In the following section, I will discuss Amish uses of the German language. Because German is not used extensively in the Amish community, this discussion serves mostly as context for the analysis of the use of English and Pennsylvania Dutch that will follow.

\footnotetext{
"There are a lot of Words I Don't Know in this Book"
} 
German is the language used least often by the Amish community and exists entirely for religious purposes. German can be heard only during religious ceremonies such as church services, weddings, and funerals. The German language used by the Amish, however, is not the same German taught and spoken in modern day Germany. Amish German, called High German or Old German by the Amish community living in Hanley, is referred to by linguists as Alemannic German. To illustrate the difference between Alemannic German and Modern German, Matthew told me this story:

I had an uncle who was stationed in Germany and fought in World War II. When the war was over, he decided to stay in Germany. I was very sad that he did that because it is against our beliefs to move away like that. Whenever my Uncle visited, I had a very hard time understanding his words. His German was different than ours. The words were even different.

An example of this variation in word meaning can be found in the name the Amish give to their religious language, "high German." I asked one native German speaker at the University of Louisville about this phrase, and she told me that today in Germany, high German, or hooh Deitsch, refers to the German used by the elite class (Iancu). However, I asked two of my interview participants in follow-up meetings if they recognized the term hooh Deitsch, and neither of them knew what the word meant. Both of these participants describe themselves as fluent readers of the German Bible. This illustrates the disconnect between modern German and Amish German, so much that I argue that the German used by Amish speakers should be categorized separately from modern German, and as such, I refer to the German used by the Amish as Amish German. 
Amish German is only spoken or read by the Amish; they never write this language. The Amish Bible is printed in Amish German and is purchased by Amish church members in Sugar Creek, Ohio. Matthew showed his Bible to me, and it looked much like an English Bible with old-fashioned font and two columns on each page. As I discussed in chapter two, Amish schools teach Amish German spelling and reading on Friday afternoons, but Amish German is mostly acquired by listening to sermons at Church and singing Amish German hymns during church services.

Every interview participant stated that of the three languages, they were least fluent in Amish German. This is not to say that church and faith are not at the center of Amish life; to the contrary, there was general agreement among participants that preserving Amish German for religious services was important. This concept is not foreign to readers who are familiar with the Catholic Church's practice of holding sermons in Latin although most Catholics do not understand much Latin. In the interest of full disclosure and ethical ethnographic practice, I must acknowledge I cannot with complete confidence argue that some Amish do not understand Amish German at the same rate they understand English or Pennsylvania Dutch, as I myself do not understand the language and have no way of testing language comprehension. However, I can attest to what I was told and what I saw during a wedding to which I was invited. During the wedding reception, I was seated with several unmarried Amish men in their early twenties. When the Amish German hymnals were passed around for after-supper singing, I asked the man sitting across from me if he would tell me the title of the hymn book. He looked at the title, and then asked the two men sitting beside him if they knew 
the title. They did not. He then leaned in close to me and said "there are a lot of words I don't know in this book,"

\section{"To Speak Pennsylvania Dutch is to be Amish"}

The Pennsylvania Dutch language is a dialect of German. This dialect is still used by the Amish in order to preserve their faith and culture. Linguistic scholars generally agree, as David Crystal puts it, that "two speech systems are considered to be dialects of the same language if they are (predominantly) mutually intelligible" (8). Pennsylvania Dutch is spoken by several groups residing in the United States whose ancestors immigrated during the same period as the Amish, but today, the language is most closely associated with the Amish. In Holmes County, Ohio, where Naomi grew up, many of the English people speak Pennsylvania Dutch. She told me "When I was a little girl there, a lot of people—especially the older people — spoke Pennsylvania Dutch, even if they weren't Dutch [Amish]."

Similarly, Naomi's husband, Ezra, said "in some of the areas where there are a lot of Amish people living, like in Paradise, Pennsylvania, or Holmes County, Ohio, or even in Sugarcreek, Ohio, a lot of the older English people speak Pennsylvania Dutch. It's just their heritage." Many participants reported that their English school teachers could speak some Pennsylvania Dutch. Ruby, a woman who invited me to drink coffee with her at her kitchen table, told me a story about meeting an English woman who could speak Pennsylvania Dutch. She said:

I was in Okalahoma with my girl [daughter] and a woman heard us speaking to one another. She started speaking to me in the same language, 
and I was so surprised! She had German ancestry too, and her family had passed this language down through the generations. I really liked talking to her. I felt like we had something in common. She wasn't Amish, but she sounded Amish.

Similarly, Daniel, a former Amish man living in the community who is now a Mennonite, told me that despite the fact that he no longer uses the Pennsylvania Dutch language in his own life or faith, he remembers the language from the time in his life when it was important. He told me:

Whenever children from the neighborhood come to our house for ice cream, I speak Pennsylvania Dutch to them. They are so amazed and confused because here I am, living in this house that they see as being very worldly—and I speak their language. ${ }^{14}$ They know I'm not Amish-I don't look Amish, I don't have the beard, I drive a car-but yet I sound Amish to them. They don't understand, and they love it. It doesn't scare them; it makes them laugh.

This story, along with the fact that whenever interview participants referred to people who had left the Amish faith as those who "aren't Dutch anymore" points to the fact that just as scholars like William Labov, John E. Joseph, and Joshua A. Fishman show, language and identity are intimately related in this community.

\footnotetext{
${ }^{14}$ When Daniel referred to his "worldly house," he was referring to the electricity in his house and the modern appliances such as a dishwasher, an electric stove, and the seemingly brand new energy efficient washer dryer set I observed Anna use whenever I came into their house.
} 
Although Pennsylvania Dutch is a derivative of German, the language no longer resembles German as it once did. In fact, interview participants described the language as "low grade German" or "German slang." Perhaps because it is seen as a slang language, the Amish do not regard this language in the ways they regard English or German. For example, Pennsylvania Dutch was never a standardized, written language. This fact causes anxiety for some of my interview participants, and especially for Caleb, who spoke at length about the subject during my interview with him in his blacksmith forge. He said that it was "ironic and sad" that Pennsylvania Dutch is not a written language, but he had heard there was an attempt to print and preserve Pennsylvania Dutch at a college in Wooster, Ohio. Part of this effort, he said, involves putting books and The New Testament into Pennsylvania Dutch. Regardless of my efforts, I could find no evidence of this project. ${ }^{15}$

Despite the fact that the language is not written and the Amish, therefore, do all of their writing in English, interview participants all said they felt they had a better knowledge of Pennsylvania Dutch than of English. Abigail, a quilt-maker who said she'd feel "handicapped" without knowledge of the English language, said Pennsylvania Dutch is "the language that's always on the tip of my tongue." When I asked her if she dreamed in Pennsylvania Dutch or English, she said she "suspect[s] it's Dutch." I asked Grace, who at 20 years old is younger than Abigail (who is 48), if she thinks in Pennsylvania

\footnotetext{
${ }^{15}$ I contacted four different professors at Wooster College, a small liberal arts college: professor of anthropology David McConnell who researches the connections between education and modernity in the Amish communities in northeast Ohio; McConnell's research partner and professor of sociology Charles Hurst; and Beth Muellner and Mareike Herrmann; professors of German. Although McConnell, Hurst, Muellner, and Herrmann all seemed interested in my work, none of them had heard of or were involved in this project.
} 
Dutch or English. She said "I think in both. They come equally easy to me." I asked her if she thinks older people in the community think in Pennsylvania Dutch or English, and she replied, "they probably think in Pennsylvania Dutch. We younger people probably use English more than they did when they were younger." There will be more information on generational differences to come.

If English is the only written language of the Amish and German is the language used for religious services, one may ask why Pennsylvania Dutch is necessary at all to the Amish. The Mennonites, for example, have seemingly decided that Pennsylvania Dutch is not necessary. In the Mennonite community, Pennsylvania Dutch is not a requirement, only an option. Anna, a Mennonite woman known for her homemade jelly, has always spoken English, although her grandmother did speak Pennsylvania Dutch. She said "the church in my area decided to not pass that language on to their children. We only use English, and this is a change that has occurred within the last few generations." When I asked her if she had any emotional tie to Pennsylvania Dutch because it was the language of her grandmother, she said "No. The only reason I'd want to know how to speak it is because it would be convenient to know to speak to the Amish people living in this neighborhood and especially to the children who haven't learned to speak English yet."

But, as I have discussed, the Amish associate Pennsylvania Dutch with their identities as followers of Christ and the Amish faith. Caleb, who said that Pennsylvania Dutch "defines a sense of home" for him, called Pennsylvania Dutch an "Amish birthright" and sees preserving the language as part of maintaining Amish beliefs. He told me: 
Our ancestors came to what became the United States between 1730 and 1735 to preserve our beliefs. We had to preserve Pennsylvania Dutch, but we had to learn English to exist in the United States. Protecting Pennsylvania Dutch is about protecting our rights to our faith. When we pull away from Pennsylvania Dutch, we lose it. Whenever young people start to leave the Amish faith, the first thing they do is start to insist on only speaking English. To speak Pennsylvania Dutch is to be Amish. Equating a language with a set of values or religion is not uncommon. John Duffy found similar patterns among the multi-lingual (but often mistaken as illiterate) Hmong people of Laos. In fact, Duffy found that "Hmong narratives link the loss of a writing system to the death of the Hmong king and the exile of the Hmong from their homelands in China" (37). But Caleb's statement also reveals that Caleb sees the Pennsylvania Dutch language much like M. M. Bakhtin, who says language is "not a system of abstract grammatical categories, but rather... a world view" (271). This attitude is seemingly prevalent in the community, as other participants made similar assertions. Bethany, a dry foods store keeper, said she saw Pennsylvania Dutch as an important way to link her to her forefathers. She explained: “it's very important for the Amish to stay connected to our ancestors. Speaking this language is one way we do that." Joel, a furniture maker, mentioned his ancestors frequently when he talked about Pennsylvania Dutch. He said "Pennsylvania Dutch connects me to my ancestors. Maintaining our language is our way of maintaining our connection to our ancestors. This language is our mother tongue, but we wouldn't get too far if we couldn't speak, read, and write English in this country." The fact that the Amish cling to Pennsylvania Dutch for religious and ancestral identity 
and yet consistently convey the necessity of English points to the reality that despite the Amish desire to live "not of" this world, they, as an immigrant group, have at some point been affected by the English imperative present in the United States. ${ }^{16}$ I will discuss this in more detail later in this chapter.

Despite the reverence with which the Amish community regards Pennsylvania Dutch, the language is suffering and may be in danger of what linguists call language death. A language is, as Crystal says, "dead when no one speaks it any more" (11). In the case of Pennsylvania Dutch, it is not that no one speaks the language, but presently, no one speaks it in the way it was spoken before. Instead of being a language independent of any other linguistic influence other than its German origin, Pennsylvania Dutch is now saturated with English words and phrases because the original Pennsylvania Dutch or German translation has been forgotten by or never taught to the native speakers. According to participants, this language saturation and change has occurred more rapidly in the last three decades. This phenomenon has been caused by two major influences: the material needs of individual Amish families and the assimilation of the Amish into American — and, thereby, English only-literacy practices.

Other interview participants, in addition to Caleb, shared their concerns about the current state of their home language. Sometimes these concerns were stated only as observations about vocabulary knowledge. The school teacher, Hannah, for example, noted that her grandmother knows many more Pennsylvania Dutch words than she does. She said "being around English speaking people so often seems to make Pennsylvania

\footnotetext{
${ }^{16}$ See Bruce Horner and John Trimbur's 2003 Braddock Award winning article "English Only and U.S. College Composition" for more on the U.S. English literacy imperative and its effect on writing education.
} 
Dutch less recallable." Similarly, Samuel, a small engine mechanic, stated that there were many Pennsylvania Dutch words he simply does not know, and English words often stand in the place of the gaps in Pennsylvania Dutch vocabulary. This idea was repeated by Faith, a woman who invited me to sit beside her as she sewed a quilt for her granddaughter and said:

I've noticed more and more English words mixed in with the Pennsylvania Dutch words. For example, I had always thought that the Dutch word for porch was just "porch," but then I remembered that my grandmother called it something else. My friend across the road said that she remembered her grandmother calling it something else, too, but she can't remember what the word was. Seems like the older people always knew the language better than we did.

Other participants, however, spoke more gravely about the amount of English present in Pennsylvania Dutch. Caleb told me: "there is an alarming amount of English in Pennsylvania Dutch. I'm concerned that if we continue to pull away from our home language, we'll pull too far away from our ancestry. The language keeps Amish people in the circle." He later added "It's already to the point where children from Lancaster, Pennsylvania and Holmes County, Ohio have such different dialects that they have a hard time understanding one another." Caleb suggested their trouble came because the language is not written and, therefore, is not standardized. Likewise, Naomi told me: "I heard that Pennsylvania Dutch is the hardest language to learn because there are so many varieties. And you have to know how to speak English in order to understand all of Pennsylvania Dutch because there is so much English in the Dutch." 
There were some interview participants, however, who are not concerned about the state of the language. Ezra noted that just as Amish children pick up words from English speakers, there are many instances of English people learning Amish words, too, and this is the natural result of different cultures living among one another. He said "my wife, Naomi, told me that her friend said 'nay' to her instead of no. 'Nay' is a Dutch word. She learned that by listening to the Amish." In the same vein, Adam, another furniture maker, said he is not worried that the Pennsylvania Dutch language has changed much. He said, "these changes are just like the changes you see in English with dialects-the slang words people use in Boston aren't the same words used in Atlanta. And in the Amish community, you don't have to go too far to hear these different dialects. It makes it hard for the children, but the adults figure it out."

I could not help but wonder, however, if some interview participants were making the problem seem less serious than it is because I am an outsider. Thus, when I attempt to be a reflexive ethnographer and follow in the traditions of ethnographers whose research I respect (Charlotte Davies; Pamela Takayoshi and Katrina Powell; Patricia Sullivan; Mary Louise Pratt; Thomas Newkirk; Gesa Kirsch and Peter Mortensen), I can understand why this intensely private community would be so hesitant to share the community's literacy problems with me-who, to them, must represent the mainstream education from which their parents fought to protect them. Participants who did express concern over the language issues in the community did so only after reemphasizing that their thoughts were not criticisms of the teachers or of the school. Another bishop, Luke, for example, explained the amount of English present in Pennsylvania Dutch resulted 
from the fact that $7 \%$ of the Amish in Holmes County are farmers now, whereas when he was a kid, the number was closer to $90 \%$. He said:

That's why the language has changed so much. People can't farm. They have to have businesses or work for English business owners. It's a loss to our heritage. But every school district is different. Our school district is doing a really good job. They're hosting German spelling bees for the children so that they can learn German spelling and language. The school doesn't teach Pennsylvania Dutch, you know. Just English and German. Pennsylvania Dutch is for home and family. But when people have to leave their home to work for English people, they speak English more often, and the Dutch suffers.

I suspect because I am an English teacher, Luke thought I was asking questions in order to write about Amish education specifically. ${ }^{17}$

But as Luke's comment shows, the problems with Pennsylvania Dutch are not failings of the Amish school system. In fact, I argue instead that the schools-seen by many as the primary site of English acquisition—do their job too well. The Amish are perhaps too good at speaking, writing, and reading English, and as time passes, the

\footnotetext{
${ }^{17}$ It's worth noting, too, I had to do a little work to get an interview with Luke. Luke was approached by a newspaper reporter five years ago who asked him questions about the Amish community. The reporter then printed unfavorable comments about the Amish in the local paper and used Luke's name as his source. In addition, Luke and one of my primary contacts, Thomas, do not share a pleasant relationship, and this paired with his experience with the reporter initially made him unwilling to talk to me. In an effort to obtain an interview with him, I wrote a letter to him in which I listed the exact questions I wanted to ask him, explained the reasons I wanted to ask him the questions, and offered to show him other books that had inspired my research. (See this letter in Appendix H.) After reading my letter and talking to my other primary contact, Rebekah, Luke not only agreed to meet with me but also suggested I talk to his wife, Ruby.
} 
Amish seem to become even more English literate with each generation. There is even a very noticeable difference between the accent of different generations of Amish people living in Hanley today; the older people living in Hanley have a thick, distinctively Amish accent, while the young people sound more like southeast Ohio English speakers. The effect of Amish families turning away from traditional farming is not only the appearance of more Amish business and Amish workers in English-owned business, but Amish families have had to relocate and, therefore, scatter what were once cohesive, large Amish communities across the United States. Now, Amish communities are much smaller than they were three decades ago, and Amish people are appearing in places where they were once unfamiliar. For example, a small community of Amish families just moved to a Kentucky city just outside of Louisville, and this move generated a lot of attention from the local media (Associated Press). The effect of this scattering of Amish communities is that even though the Amish population as a whole is growing, communities are shrinking, and as Crystal shows, as minority communities are scattered on the fringes, their "chances of [...] keeping their ethnic language alive are minimal" (11).

In this section, I have explained the purpose of Pennsylvania Dutch and shown how my interview participants associate this language with home, family, ancestry, and faith. In the next section, I will address the role of English in Amish life.

\section{"An Alarming Amount of English"}

As I discussed in chapter two, the Amish learn to speak English upon going to school. Some children are exposed to English-speaking outsiders more often than other 
children, and thus, these children go to school knowing more English. Regardless, the Amish see school as the primary site of English acquisition, and as my interviews and scholars like Andrea Fishman, John A. Hostetler and Gertrude Enders Huntington, and Stephen Bowers Harroff show, school is conducted entirely in English with the exception of German reading and spelling lessons on Friday afternoons. In this section, I argue that English, a language to which the Amish feel no real ties, is a function of practicality and especially of economic and nationalistic imperatives dictating the use of English in the United States.

Because I saw strong emotional attachments to the Pennsylvania Dutch language in the interviews I conducted with Amish and Mennonite individuals, I asked interview participants to talk about the role of English in their lives. I asked Ruth to talk about instances in which she uses English. She said, "I use your language whenever I talk to my English neighbors, when I go to the grocery store, or when I go to the doctor." I noticed she used the phrase "your language" whenever she referred to English, as if she did not feel English belonged to her-or she belonged to English, so to speak. Before I knew the Amish do all of their writing in English, I asked a few interview participants why they thought church appointed "scribes" write letters for The Budget in English. Ezra said he thought it was in English so "you (English speaking) people can read it." Like Ruth, Ezra seems to be emotionally removed from English. These statements point to the distance the Amish feel from the language they know best and reflect the findings in psycholinguistics by scholars like Aneta Pavlenko, Mary Besmeres, Jean-Marc Dewaele, and Michèle Koven who show that speakers of multiple languages often choose the language to which they attach the most emotion, as in the case of "Wendy," a case- 
study subject of Pavlenko's who reacted most to emotions expressed in her fourth language, Italian. What this illustrates is that emotional ties to specific languages-no matter what the language's role may be in the speaker's life - are very real to the speaker, and the lack of emotion with which the Amish regard English is especially interesting considering that the Amish do all of their writing and most of their reading - two acts many participants expressed love for-in English.

Other participants talked about the importance of knowing English. As I discussed in chapter two, participants want to be "neighborly" and speak to their English speaking friends, neighbors, and customers in English. Bethany, who owns and operates a dry goods store, said: "I couldn't imagine life without speaking English. I wouldn't be able to talk to my neighbors, and running this business in this area would be impossible. I have a lot of English customers. The Baptist church over in Grover Fields buys a lot of my angel food cakes for their church suppers." I asked Bethany if she used English for any interactions other than with those who exclusively spoke English, and she replied, "No, English is only for business and neighbors." Indeed, some participants told stories about the trouble they had interacting with English speaking adults when they were children who had not yet gone to school. Naomi told me this story:

When I was a girl, my mother would send me and my sister to the store to pick up a few items for the household. She'd write a note in English, and we'd go in and give it to the shopkeeper who would read the note and get the items for us. He tried to make small talk with us, but we couldn't understand. I think he thought we were shy. People often see Amish children and think they look American and assume that they speak 
English. I don't know if that shopkeeper ever figured out that we couldn't understand him.

Likewise, Jacob says the Amish have to speak, read, and write English "to know what was going on." Caleb took this a step farther by saying that "we had to learn English to exist in the United States."

Comments like Caleb's and Naomi's who exclaimed "We have to speak English! What would we do when we went to Wal*Mart?!" suggest the Amish believe that just as to be Amish is to speak Pennsylvania Dutch, to be American is to speak, read, and write English. Like Duffy's finding that the Hmong were "invited" to literacy "as a necessary tool for economic advancement and for political participation on the national level" (122), the Amish are invited, as Edwin Black puts it, "not simply to believe something but to be something" (172). In this case, the Amish are invited, through English literacy, to be American. Only through English literacy do they feel like a part of what Benedict Anderson calls an "imagined community;" the Amish feel that speaking, reading, and writing English makes them part of the American community, while mainstream America still sees the Amish as outsiders. But it's also important to note the Amish do not necessarily feel American, either. Caleb, after all, said the Amish had to speak, read, and write English in order to exist in the United States-not to be American.

The interview participants, no matter how separate from the world they may seem or aim to be, have the air of being motivated at least in part by the material and global value of English, the language appropriately described by Catherine Prendergast as "capitalism's first language" (2). Comments I discussed in chapter two that point to "being handicapped at Wal*Mart"—a comment made by two participants—and those 
that point to the importance of the English language and literacy practices illuminate the fact that when it comes to language and literacy, the Amish are very much aware of how, to borrow their term, "crippled" they would be, both financially and socially, if they did not write, read, and speak English. Although most participants claimed their primary motivation for learning English and practicing English literacy skills was to communicate with English speaking people in order to, as they often said, "be neighborly," upon prompting, most acknowledged that English was necessary for, as Jacob put it, "getting along financially in the U.S." Similarly, J. Elspeth Stuckey argues the "usual speculations about the nature and need for literacy are misguided" and what seems like values for reading, writing, and speaking in this country are simply veiled values for the ability to pay (vii). In the case of the Amish, not only is the ability "to pay" becoming more and more important, but what is also arising as a result of the farming conditions mentioned in chapter two is the increasing importance of the ability to work in Englishcentric settings. Like so many other citizens who were "invited" to literacy-which Claude Levi-Strauss called "an instrument for the enslavement of mankind"- the Amish are working in English-owned businesses like saw mills, factọies, contracting companies with increasing frequency, thereby reinforcing the importance of English literacy skills for Amish community survival.

The increasing frequency with which Amish community members are forced into the American workforce by changing local and global economic conditions certainly affects this prioritization of English literacy. The 1972 Supreme Court Case Wisconsin $V$ Yoder found that Amish children could not be forced into compulsory education after $8^{\text {th }}$ grade, and to do so would violate their parents' right to freedom of religion. The 
court's opinion states explicitly that students "are taught subjects such as English, mathematics, health, and social studies,"- notice that the court puts to rest any fears that the students may not be learning English in Amish schools-but even more importantly, the dissenting opinion written by Justice William O. Douglas points specifically to how Amish education affects the future careers of Amish students. Justice Douglas writes:

On this important and vital matter of education, I think the children should be entitled to be heard. While the parents, absent dissent, normally speak for the entire family, the education of the child is a matter on which the child will often have decided views. He may want to be a pianist or an astronaut or an oceanographer. To do so he will have to break from the Amish tradition. It is the future of the students, not the future of the parents, that is imperiled by today's decision. If a parent keeps his child out of school beyond the grade school, then the child will be forever barred from entry into the new and amazing world of diversity that we have today. (emphasis mine)

Even though the opinions vary, what is consistent in these opinions is a concern for the instruction of English literacy and how this instruction may affect Amish students' potential to enter the workforce. This corresponds with Brandt's analysis of literacy and economics in which she states

If the ability to read and write was once regarded as a duty to God or democracy, it is now, according to the government, a duty to productivity, and one with increasingly sharp consequences for those not in compliance. Unrelenting economic change has become the key motivator for schools, 
students, parents, states, and communities to raise expectations for literacy achievement." (25-26)

Therefore, the fact that Amish schools focus almost entirely on English literacy in a time when Amish men and women are entering the mainstream American workforce with increasing frequency is probably not accidental. ${ }^{18}$ Amish school organizers understand, as Brandt says, "no teacher or policymaker at any level can ignore the power of the country's economic system, its direction of change in the twentieth century, and the implications that change brings, especially now, for literacy and literacy learning" (43).

As is shown not only by my findings with the Amish but also in the research done by scholars like Sylvia Scribner and Michael Cole and Niko Besnier, communities who use languages originating from foreign sources often experience some kind of change in their home language. As in the Nukulaelae community of which Besnier writes, English has become essential for, as Besnier puts it, "academic and economic success" for the Amish (55). As in the Nukulaelae community, the result of multiple languages converging in the Amish community is that one has lost favor-Gilbertese, in the Nukulaelae's case, Pennsylvania Dutch in the Amish's case - and as Besnier says of the Nukulaelae, "will probably disappear within a generation" (54). If we apply Besnier's argument to the Amish, one could argue the lack of an ability to write or produce Pennsylvania Dutch is the cause of the decrease in Pennsylvania Dutch usage, and like Gilbertese, I predict that Pennsylvania Dutch will be lost or abandoned by most speakers within the next few generations.

${ }^{18}$ As I discuss in chapter two, Amish school is conducted entirely in English with the small exception of two hours of Alemannic German on Friday afternoons. At most Amish schools, children are not allowed to speak Pennsylvania Dutch, even on the playground. 
But the Amish do not want to be seen as a community who learned English only for material needs. Although many Amish families are what we English people would call wealthy, Anabaptist churches warn their parishioners against materialism. Initially, I did not think these values were that extraordinary, as all Christian churches teach against coveting thy neighbor's belongings, until I reflected on two conversations I had while conducting interviews. The first of these conversations was with Samuel, the Mennonite scribe. He asked me why I wanted a Ph.D. In an effort to simplify my answer, I told him that in my field of work, a Ph.D. offers better jobs, more job security, and more money. He replied, "Yes, that is important in your world. I understand." The second incident occurred when talking with Caleb. When I asked him what he saw as being the benefits of speaking multiple languages, he replied, "there are no financial benefits." I was caught off guard by this response, so I explained there could be multiple kinds of benefits, such as emotional, intellectual, or personal. His reply, I believe, is very telling: "Oh, right. I thought you meant that the way your people use that word." So to argue that this community is motivated by money to speak, read, and write English seems to suggest I'm arguing that the community is a victim of false consciousness. That argument, however, is not the one I want to make. Instead, I argue, like Stuckey and Prendergast, that the material value of literacy and especially English literacy in the United States is so significant and normalizing that even the Amish—a group who desires to be not "of this world," is greatly affected.

The English imperative in the United States has affected the Amish in another way I did not anticipate. As I explained in chapter two, on six occasions during my twenty-five interviews, I encountered attitudes toward other non-Native speakers living 
in the United States I can only describe as xenophobic and racist. These attitudes were apparent whenever the participants explained that, in their view, speaking Pennsylvania Dutch in front of English-only speakers was rude and "unneighborly." Adam told me: "English is our public language. It's rude to use our language in front of the public." Likewise, Eden and I shared this exchange:

Eden: Before I married Adam, I worked one summer as a strawberry picker. I worked with a lot of Mexican men. There weren't any other Amish. These men only spoke Spanish. I thought it was really rude that they spoke Spanish in front of me. They knew I couldn't speak Spanish. It made me really uncomfortable. I always wondered if they were talking about me.

TA: What language did you think they should speak?

Eden: English.

TA: Do you think they could speak English?

Eden: Well, I don't know. But this was in the United States.

This conversation illustrates not only that the Amish have been assimilated into the imagined community that holds that they, as Americans, should speak, read, and write English but also that all immigrants should speak English. While I would not claim this 
attitude is universal throughout the entire Amish community, I found it often enough in my own interviews to mention it here.

Unlike the Amish, who believe they should speak English but maintain their home language, as I have already explained, the Mennonites have moved away from Pennsylvania Dutch and Amish German altogether. While the Amish maintain their Pennsylvania Dutch largely for religious reasons, Mennonites have abandoned Pennsylvania Dutch toward religious ends. Unlike the Amish, Mennonites are evangelical, and Pennsylvania Dutch would therefore be a hindrance to bringing outsiders to their faith. It is in the best interest of the Mennonites, then, to not only speak English but to seem like "English people" in appearance, accent, and lifestyle. Anna, a Mennonite woman, told me this change has occurred in her lifetime. She remembers her grandmother using Pennsylvania Dutch at home while she was growing up, and as I've already mentioned, the church in her area decided against teaching Pennsylvania Dutch to the next generation. Samuel confirmed that this had occurred in his own church, and told me, "According to what I read in The Budget, this has happened pretty universally throughout the Mennonite community." Yet another Mennonite man, Daniel, explained to me that "Mennonite church members want to speak English not only well but without an accent to attract English speaking new members. Also, learning to be Mennonite presents enough challenges without adding the acquisition of a new language onto the list of requirements."

In this chapter, I argued that although orality and literacy are not one and the same, the normalizing force of literacy and especially English-only literacy in the United States have changed Amish literacy practices, and language practices have followed. 
Amish literacy and orality are dictated by four major ideals: religious faith, heritage, nationalism, and economic and personal utilitarianism and therefore we see again that the values of the community inform their language and literacy practices. Religious beliefs motivate the Amish to maintain their home language, Pennsylvania Dutch, and to preserve religious ceremonies and texts in Amish German. Religious beliefs are also the source of the Mennonite church's decision to abandon Pennsylvania Dutch and Amish German. Negative attitudes about immigrants and English literacy in the United States have caused the Amish to conduct all written business in English and abandon any writing in Pennsylvania Dutch and Amish German. Because of these attitudes, the Amish educate their children almost exclusively in English because, as the Amish understand, English literacy is necessary to their survival and acceptance in the United States. Despite the fact that the Amish want to be not "of this world," English literacy is undeniably important in this country. But if the Amish are giving up the component of their literacy practices tying them to their German speaking ancestors, how do they maintain Amish community? Not surprisingly, the answer to this question is also found in Amish literacy practices. In the next chapter, I argue that The Budget newspaper creates a sense of Anabaptist community for Amish and Mennonite readers. 


\section{CHAPTER FOUR}

\section{“TO EVERYONE OUT THERE IN BUDGET LAND": THE NARRATIVE OF COMMUNITY IN THE INTERNATIONAL NEWSPAPER,}

\section{THE BUDGET}

As I have discussed in previous chapters, The Budget, a newspaper printed each week in Sugarcreek, Ohio is a text that is essential to the Amish community. Since 1890, the local (non-Amish) Sugarcreek paper has published two editions: the "local" edition, which prints local Sugar Creek area news, and the "National Edition," a weekly Amish and Mennonite section which as its subtitle claims, "Serv[es] the Amish-Mennonite Communities Throughout the Americas."19 The editors of The Budget are not Amish but are professional journalists who manage subscriptions, distribution, and editorial duties. The Budget arrives in the mailboxes of Amish and Mennonite readers in Hanley every Thursday.

The Budget is a unique newspaper in that it features no writing by professional journalists. There are no articles, stories, or photographs in The Budget. Instead, the paper is compiled from letters written by locally appointed "scribes" who report on the news of their church districts. These letters come from 34 American states, three Canadian provinces, and eight foreign countries where Mennonite missionaries serve,

\footnotetext{
${ }^{19}$ When I refer to The Budget from here on, I am referring only to the National AmishMennonite edition.
} 
including Ukraine, Belize, the Dominican Republic, Haiti, Guatemala, Romania, Nicaragua, and Ireland. In addition to these letters, The Budget features several other regular sections that are generated by unpaid, amateur journalists including "Cookin' with Maudie," a column where "Maudie" shares a recipe and cooking advice; "Es Pennsilfaanisch Deitsch Eck" ("The Pennsylvania Dutch Puzzle Corner"), a column where readers are challenged to translate an excerpt of text written in phonetic Pennsylvania Dutch into English; “Cards Announcements," a section where readers, for a fee, submit names and information of friends and family members who are ill or grieving and in need of cards of support and encouragement; "Showers Announcements," where readers, for a fee, submit names and information of friends and family members who are in need of gifts or money (usually because the individual or family has suffered a death, house-fire, or illness); "Information Please," which I will discuss at length later in this chapter; and "Ponderings and Musings from Budgetland," a space for poems, jokes, stories, and drawings created by Budget readers. The content is generated entirely by users and is therefore more akin to social networking websites or blogs than to a traditional newspaper. In fact, when I presented an early version of this chapter at the Conference on College Composition and Communication in 2007, I was placed on a panel about blogs. Since the Amish community does not use networking sites or blogs to create a sense of community, The Budget is a literacy artifact resulting from the community's needs and values, or as Ann Ruggles Gere says, an example of "literacy constructed by desire" (80).

While there are other texts that serve Amish and Mennonite communities, including another newspaper called Die Botschaft ("The Message"), like most Amish 
communities, the Amish families in Hanley subscribe exclusively to The Budget. There are Amish communities in the United States whose citizens subscribe more often to Die Botschaft, such as the community near Lancaster, PA studied by Fishman (43). However, as Hostetler shows in Amish Society, The Budget is much more popular and "has been an important institution, serving as the major means of communication among all Amish settlements, informing them of agricultural activities, visits and travels, sickness, accidents, and weddings" (377). Hostetler describes the difference between The Budget and Die Botschaft thusly: "some Budget writers are former Amish members, and since some of them are under the ban [excommunication] and use their writings to "liberate" the more orthodox Amish, [some Old Order] Amish readers wanted an alternative. A Committee of deacons is responsible for 'keeping out [of Die Botschaft] the writings of unsound writers, especially those who have left the faith of our fathers"” (377). But in Hanley, The Budget is the preferred text. In fact, only one participant in this study, Jewel, even mentioned Die Botschaft. She told me, "when I was growing up, my family subscribed to a different paper, but we read The Budget now." When I asked her if the other paper was Die Botschaft, she was very surprised I knew about the paper. Interview participants expressed that the importance of The Budget cannot be overstated. As I have shown in previous chapters and especially in chapter two, community is essential to Amish identity, and as one interview participant, Caleb, put it, staying near the community "keeps Amish in the circle" and closer to their faith. Therefore, it is only natural that the second most important text after The Bible to the Amish and Mennonite community would be one that is created by the community toward the end of maintaining a sense of community among Anabaptist readers all over the world. Like the Nukulaelae 
community which, as Niko Besnier writes in Literacy, Emotion, and Authority, depends on letter writing to communicate with family members who no longer live on the island, Amish community members depend on The Budget to be the textual link with the Anabaptist world outside of their immediate community. It is my assertion, then, that the Amish, a community known for avoiding modern technology, use this newspaper, a technology of which they do approve, as a way to create an international Amish identity and community. As I have shown and as the title of this dissertation suggests, a central tenet of Amish beliefs is to be separate from society, or as I Peter 2:11 dictates, "in the world but not of it." I argue that one strategy the Anabaptist community employs toward staying separate from the world is to stay close to the community that shares their beliefs, and the way the Amish accomplish this is to stay in touch with other Amish people all over the world through The Budget. The Budget, then, serves as an example, like the models of education and language learning, of literacy practices shaped and determined by the core values of Amish life: faith, collaboration, and preservation of community. Community is created and maintained in The Budget by two distinct techniques that I will discuss in this chapter. First, it is clear that scribes are acutely aware of their role as representatives of the community for which they write. In chapter two I wrote about the work of a Budget scribe as a collaborative effort between the actual composer of the letter and the community who supplies the content of the letter. And while Budget scribes seem to be aware of an outside audience and are clearly mindful of how they present their community to that audience, the tone is consistent with one used with friends and neighbors. In the forthcoming section, "“Open, Friendly, and Active': Representing Community and Self," I will show how Budget scribes work to create 
positive portrayals of their communities and an ethos of religious devotion, good humor, hospitality. In "A Trusted Text," I will expound upon the use of The Budget as a source of information, Budget scribes' adherence to conventions created by the paper's English editorial staff, and the controversial but undeniable element of entertainment in Budget letters.

\section{“Open, Friendly, and Active": Representing Community and Self}

During my interview with Samuel, a Mennonite scribe, I asked him to describe how he hoped readers of his Budget letters would interpret his community according to his representation of it in The Budget. He responded, "I hope that people would see our community as one that is open, friendly, and active." Indeed, after reading The Budget each week for one year, it is clear to me that many scribes have this same desire. For this reason, I use Samuel's words to organize this section. As I analyze the ethos created by Budget scribes, I will focus specifically on representations of the community as one that welcomes outsiders, anecdotes describing community activities, and letters detailing the religious devotion of scribes, the communities they describe, and the audience for which they write. Before I launch into this analysis, however, I want to say a bit about the tone of letters written for The Budget.

As a non-Amish reader studying these letters, I was surprised that Budget writers seemingly assume their readers are already familiar with characters, setting, and plots that reoccur in their letters. These conventions assume a community of faithful readers. This community is created by relating news of family and friends in a tone one might expect of someone who is acquainted with the reading audience. This creation of community 
that The Budget affords the Amish is not unfamiliar to readers of small town newspapers, local gossip columns, church newsletters, or even e-mail listservs. ${ }^{20}$ What is different about the Amish community created by The Budget, however, is that it is an international community, a community that is, as Benedict Anderson shows in Imagined Communities, an "imagined religious community" (12). Fishman calls this "the larger community, the one including all Amish everywhere" (40). Letters found in The Budget come to Sugar Creek from as far away as Romania. But the tone of the letters with European or Latin American origins is no different than those originating in Sugarcreek. The Amish scribes of the international letters maintain the uniform tone of familiarity with the reader. While all four past and current Budget scribes interviewed for this study said that they imagined their friends and family as their audience, they were also conscious of their unknown audience. Samuel said of his unknown audience, "I truly enjoy meeting people in other states who read my Budget letters. Occasionally I'll meet someone who says they like my letters. I feel encouraged by those remarks, and sometimes I feel like I need that encouragement."

There are many examples of this tone of familiarity in Budget letters. The first I will include here comes from a scribe in Geneva, Indiana who signs her letters as Mrs. Harry H. Schwartz Jr. In her letter from February 21, 2007, Schwartz includes this story: "Son Joe just drove in to show us little Laura. He had to take her for a PKU test. She weighed $7 \mathrm{lbs} 11$ ozs. Martha's sister is working for them. Roman Troyers took supper

\footnotetext{
${ }^{20}$ Some examples of these kinds of publications include Louisville's Southeast Outlook, a newspaper printed by a local church; The Louisville Defender, a publication for African American citizens of Louisville; Call and Post, a local newspaper for African American citizens of Cleveland, Ohio, and The New York Amsterdam News, a local community paper for African American residents of Harlem.
} 
at Joes' [sic] last night. Homemade ice cream on the menu" (1). In this letter, we see the use of first names only, as if Schwartz assumes that her readers will know Martha and that their son Joe has recently had a daughter, Laura. There is no explanation of these details, connections, or contexts. Schwartz also assumes her audiences will know, for example, what a PKU testis and uses the community's shared lexicon to convey the news. $^{21}$

This tone of familiarity and lack of context and detail can be attributed to the way in which Budget scribes imagine their audiences. Luke says,

I think about my parents when I write my letters. I imagine it's them reading the letter. It's like a letter to them that I allow everyone to read. But it's important that the letters aren't all about us-me and my familybut are about the entire community.

Luke includes two central focuses of Amish life — family and community--in this description of his imagined audience. Imagining his family as his audience assists him in adapting the tone of familiarity expected by Budget scribes. Samuel said that he wants his readers to feel as if they know him. He said, "when I meet people who read my letters, I sort of feel like they already know me in a way. We're already familiar." The assumptions Budget writers make about familiarity with their audience are not perceived as presumptuous by the readers I interviewed in Hanley. Married couple Joel and Debra told me that The Budget is important in their lives because it connects their family, both here and away. Debra said:

${ }^{21}$ According to WebMD, "a phenylketonuria (PKU) test is done to check whether a newborn baby has the enzyme needed to use phenylalanine in his or her body. Phenylalanine is an amino acid that is needed for normal growth and development." 
As a family, we talk about what we read in the paper. We have family members all over the country, and we keep up with their news this way. But there are also letters we follow from communities where we don't know anyone. We're grateful for those letters and to those scribes, otherwise we wouldn't know what was going on in those communities. When Caleb reads the Budget, he reads the letters from communities where people he knows live. He says he wants to know "their news." So familiarity is expected by The Budget's readers, as well, even from communities and scribes unfamiliar to the reader. Another way familiarity is demonstrated in Budget letters is that the writers refer to previous letters, assuming that the reader may remember the content of these letters. Often, this is done to correct content errors. Katie L. Yoder of Belleville, PA illustrates this best in her February 21 2007. letter: "We as scribes at times see mistakes in our letters which are not intentionally made. My letter of Jan. 30 had one line missing, which of course made for incorrect facts. White Hall district was for Isaac Swareys and Middle district for Mosie Rennos (13)." Similarly, Rudy C. Borteger makes a correction of his news from Tomah, WI with "A correction to last letter. Alvin A. Yoders and Menno P. Hochstetlers did not go to Hazleton to that funeral after all. John D. Yutzys had gone along instead" (21 Feb 2007,24$)$. These corrections indicate not only that the scribes take their responsibility of reporting community news very seriously, but they also want their readers to respect their abilities as scribes. This care to correct mistakes and report facts accurately suggests that the writers of these letters want their audience to feel as though they're getting credible, dependable news from their community. And indeed, as I explained in chapter two, scribes are respected in their communities. During the 
interviews I conducted for this study, multiple readers insisted that the success of The Budget was a credit to the scribes and that, as Ruby put it, "without scribes, we couldn't have a Budget. And how else would we get our news?" But as Brandt shows, the respect paid to the scribes in the community may also originate from the prestige paid to writers and writing in our culture. In "'Who's the President?': Ghostwriting and Shifting Values in Literacy," she argues "[b]ecause writing in our society is, at least in some contexts, elevated as a rare talent or an expression of unusual intelligence, those who engage in it well (or ostensibly so) can derive status from that perception" (561). The prestige that comes with being a Budget scribe, however, comes with a heavy sense of responsibility, and as I detail later in this chapter, scribes take this responsibility seriously because they sense that their readers rely on and trust their writing.

But however present the local, familiar audience may be in the scribe's mind, there is still a great deal of care paid to representing the community to outsiders as one that is welcome, open, and warm. Budget readers told me in interviews that they wanted their community to be portrayed as a place where others might want to live. Abigail stated that she hopes Budget readers find her community, as portrayed by Luke, as one that is "very friendly." Caleb said that he hoped readers find Luke's letters to be "community minded." Ruby, a former scribe, said that when she was writing, she hoped that readers thought her community "worked together and had a sense of humor about itself." This recognition of a desire to be represented as a community that adhere to the values central to Amish life shows that readers and writers of The Budget acknowledge that their text is shaped by the values of the community. 
Most often, this representation of the community as welcoming and warm is presented as a narrative about a community activity. The scribe who seems to be most esteemed for telling these kinds of stories is Kathy Beachy from Amanda, Ohio.

Beachy's letters were recommended to me by three different interview participants because, as Anna put it, "she's the best Budget writer." Her letters are noticeable because they are often five times longer than those written by the scribes in Hanley, and Beachy's letters are unique in that she recently converted to the Anabaptist faith when she married a Mennonite. Beachy's letters detail her conversion to the Anabaptist faith but also include lengthy narratives about community life in Amanda. One example of this kind of narrative appears in her September 24, 2008 letter:

We do rather enjoy each others' company here, I must admit, and the amount of time we spend together reflects that. This week we had a volleyball game Tues., prayer meeting Wed., work night Thurs., a fundraiser Fri. and still got together Sun. night to 'catch up'. Thursday we cleaned the church house. Our more dedicated and observant readers will note that we just had church house cleaning a few weeks ago. While I'd like to let you think that we really are that neat and tidy around here, it would be more honest to admit that we didn't get the sanctuary done during that first work night. Our school and teachers' apartment needed a thorough cleaning before the school year began and we decided the sanctuary could wait. And wait it did, until Thurs. Now we are dirt, dust, and cobweb free, at least for the time being. If you 
appreciate that sort of thing this might be the time to visit. (Though we'll welcome you just as warmly when the cobwebs return.) (31)

A month later, Beachy extends a similar invitation to readers: "If you have not seen the hocking hills in Oct., then it's no use to describe them. You'll just have to come visit, and we'll be sure to treat you to the best our area has to offer" $(15$ Oct 2008, 36).

Beach's letters clearly demonstrate this desire expressed by Hanley scribes and readers to represent the community as a fun place to live.

While Beachy's letters superbly describe the active community in which she lives, many stories like this appear in the Budget each week. The Russellville, Kentucky Willow Creek Mennonite letter from November 11, 2008 describes a fun evening for the community: "Tonight we enjoyed an evening of singing and Bible Trivia. We also welcomed John Bender with gifts and groceries, followed by a snack of cookies and popcorn" (37). Joseph, a scribe in Hanley, describes a family trip thusly: "Dads and brother Nelson headed for Cherry Valley at noon today for Jonas Byler's auction Sat. They will be coming back Mon. sometime ${ }^{22}$ Expect Nelson might work on his fishing skills while up there" (10 Sept 2008, 38). Samuel's October 1, 2008 letter demonstrates the community's involvement in schools, stating, "Most of the mothers from church gathered at school Tues. to bring hot lunch in for the teachers and their students. Our upper grades teacher, Sister Joanna Shenk's birthday being on Tuesday helped to prompt the occasion" (27).

${ }^{22}$ The use of "Dads" here is not a typo or mistake. This use of the plural is used to refer to a married couple or family. So, for example, if Joseph were reporting on Cliff and Clair Huxtable visiting Mike and Carol Brady, he'd write "Cliff Huxtables visited Mike Bradys on Sunday." I see this in The Budget a lot but less often than I initially suspected. 
The scribes interviewed for this study alluded to the ethos they each wanted to establish for themselves, and the nature of the desired ethos varied greatly among the scribes. Samuel seemed the most concerned with how he was perceived by his readers. He said he took care not to seem as if he was "prying" into the lives of the members of his church for Budget news, and when I asked if the editorial rule against printing any negative information bothered him, he said "No. Of course not. I wouldn't want to be known for reporting that kind of information, anyway." Samuel, as I have shown, is also concerned with readers enjoying his letters, and this concern is reflected in what he writes. The details he gives and the inclusion of a weekly inspirational quote points to the fact that Samuel wants to be liked by readers, both far away and locally. Luke and Joseph, on the other hand, want to be seen only as mouthpieces of local news. Both said that they did not intend to entertain readers or to, as Luke put it, "impress anyone." These attitudes about their roles as scribes are reflected in their letters. Luke and Joseph rarely include "human interest" stories, and their letters are consistently shorter in length than Samuel's. Therefore, their ethos as "reporters" rather than entertainers is established in the length of their letters, the lack of details included in letters, and the strictly "business" content of their letters.

While it is important for Budget scribes to create narratives of community, it seems critical and expected that part of this narrative would include details of the community's religious faith and practices. Therefore, scribes themselves must develop and maintain Christian ethos. This rhetorical move is seen most clearly in Samuel's letters. Samuel ends his letter each week with an inspirational quote or idea that, as he says, "give[s] everyone something to think about. Maybe they'll look for my letter next 
week and see what I have to say." Two examples of these kinds of closings are "Tomorrow is uncertain, eternity is sure" from Samuel's September 3, 2008 letter, and "Autumn is the second spring, the woods are God's flower garden, and every leaf is a blossom" from his October 152008 letter $(21,29)$. Other demonstrations of religious devotion that appear in Samuel's letters include a story about some men in his congregation who toured several European cities. Samuel reported that the tourists said, "It was interesting to see places in Germany and Switzerland where our Anabaptist forefathers lived and gave their lives for the faith" (14 Nov 2008, 34). Another example of religious faith and practice appearing in the Budget - and this example appears in many Budget letters-is details of a couple or group touring the Creation Museum in Hebron, Kentucky. Samuel's October 22, 2008 letter reports that a married couple celebrated their $10^{\text {th }}$ wedding anniversary by touring the museum. In addition to these details are many mentions of praying for community members, national leaders, and fellow citizens, and occasional uses of religious language such as Beachy's discussion of a couple's "calling to be foster parents" or her description of the religious conversion of people in her community who, as she says, "took their places among the ranks of believers and committed their lives to serving Jesus. We rejoiced with them as they sealed their vows with water baptism" (24 Sept 2008, 31).

The appearance of religious rhetoric and discussions of religious activity in The Budget is certainly not surprising considering the importance of faith in the Amish community and serves again as an example of values determining literacy practices. In fact, as the bishop Matthew told me, the friendly tone and the success of The Budget is "a manifestation of Christianity in the daily lives of the scribes who write for the paper." 
But scribes, I argue, do not simply include religious rhetoric and descriptions of faith in their letters to create ethos or represent themselves or communities as followers of the Amish faith. Religious ethos is important in creating trust among the community in the newspaper. In the next section, I discuss the elements of The Budget that illustrate the veritable trust Amish community members have in the paper as a source of information and entertainment.

\section{A Trusted Text}

With the help of editors at The Budget, the Amish community has collaborated to shape The Budget into a regulated, coherent text Amish readers have come to trust for information, Anabaptist values, and entertainment. Readers can be confident that scribes share their morals, values, and religious beliefs, making the text "safe" and dependable for Amish families. While some Amish families do subscribe to mainstream local papers in addition to The Budget, I observed that these newspapers are more of annoyance to Amish readers than a source of information. Many participants in this study complained about the advertisements that appear in the local newspaper, and the city paper in Hanley has committed many offenses against the local Amish community including photographing them for stories about barn raisings and interviewing community leaders like Matthew, the bishop who participated in this study, who claims that he was misrepresented and misquoted by the reporter who wrote the story for which he was interviewed. In addition, as Fishman shows, scribes cover news in a way that "adds details an Amishman would consider important" (45). She includes this story from Die Botschaft as an example: 
Last week a group of girls went to Ocean City, $\mathrm{NJ}$ to help prepare a summer home for use by the Christ's Home for Children, located in Paradise. Before returning home Mary King and Emma Lapp, both school teachers of Ronks R.D., went wading in the ocean. A strong undertow pulled Emma in and Mary trying to help her also got pulled in. A 24-year-old boy heard them screaming and rushed in and had Emma, but was also pulled in and he drowned. His body was washed up to shore around 3 hours later. Both girls were rescued by a policeman and other passerbys. The policeman and both girls were admitted to the hospital. Mary came home yesterday, but Emma remains in the hospital yet on a life-support system and still unconscious and showing no signs of improvement as of yet. She is a dau. [daughter] of Mr. and Mrs. John Lapp, Little Beaver Road, Ronks, PA. (45, emphasis mine)

Several elements of this story illustrate the qualities the Amish value in reporting. First, the scribe explains why King and Lapp were visiting Ocean City. Whenever scribes include stories about community members' travels, the purpose is always included, and the purpose is usually to visit family, to engage in some sort of charity work, or to enrich their spiritual lives as Christians (by visiting the Creation Museum, for example). Amish readers would want to know exactly why these two young women were away from their families. Secondly, Amish readers would want to know that the 24-year-old English boy who had been found with the similarly aged Amish girls had not been swimming with them but had only overheard their cries and came to help. Also, readers would no doubt be moved by his courage and act of kindness. Finally, this scribe included Lapp's 
parents' names and address so that readers could send letters of condolence and support. The style adapted by Budget scribes, then, is in opposition to the style of mainstream newspapers, and this opposition follows the model found by Nicholas Coles who shows that in the case of the Federation of Worker Writers and Community Publishers (FWWCP), the federation worked together to create "a literacy shaped by a sharp sense of difference from, and in many ways of opposition to, the arrangements by which large sectors of cultural life in Britain-schooling, literature, publishing-have customarily been regulated" (190).

The Budget also provides a sound source of information to the Amish, a community who values familiarity with those in their presence. I observed this phenomenon during my first interaction with the Amish people living in Hanley when I attended the funeral of my primary contact's mother-in-law, Louise. Approximately 150 Amish people came to pay their respects to this non-Amish woman and her family. I attended Louise's funeral with my parents, and upon entering the funeral parlor, Matthew, who I later came to know through this study, approached us, asked who we were and how we knew Louise. Once he understood that Louise is my fiancé's grandmother, he was satisfied that we belonged there and talked to us at length about his experiences with Louise. Similarly, Fishman talks about this importance of knowing the scribes and how authority is granted to Budget and Die Botschaft scribes based on familiarity (45). This idea is emphasized in The Budget by the fact that letters begin with the location of the scribe and that interview participants tend to read letters written by scribes they know. 
Strict conventions set by the editors at The Budget contribute to the trustworthiness, coherency, and regulation of The Budget. Matthew said of these conventions: "The editor of The Budget will not allow the scribes to say anything negative in their letters. If a letter arrives and there is negative content, the editors will remove that content. Scribes must follow the rule of doing unto others as they would have done unto themselves." When I asked about the editors, Matthew said that they were English people, not Amish. I asked if this caused any tension or awkwardness, and he said, "at wintertime they printed a picture of themselves saying 'Merry Christmas,' and this struck me as an un-Amish thing to do. I do not think Amish people would do that." Samuel, a scribe himself, said "The current editor of the Budget, Fanny Miller, is not as hard on Budget scribes as some former editors were, who were heavy-handed in their editing." When I asked if this heavy-handed editing bothered him, he said, "No, they were just looking out for the best interest of the paper." Ruby, on the other hand, found the rules of the editors to be difficult and restrictive. She said,

They required us to say as much as possible in as few words as possible. The Budget used to be shorter-like two pages of magazine paper-and was started by just a few districts in Sugar Creek, Ohio. But the paper really grew, and letters must be short so that they can fit everybody's news in there. The editors will cut pieces of letters out if they're too long. They won't print a story with a negative statement about a person, but they don't mind a sense of humor. They will allow warnings about scams, as sometimes traveling salesmen will try to scam multiple Amish communities, thinking that without technology the members of the 
communities cannot warn one another. But anything else negative cannot be printed. And they won't print announcements about cards or showers in the regular letters-those are in a separate section and must be paid for. Sometimes I found it difficult to write for The Budget because they expect extreme concision.

This practice, along with the exclusion of "negative news" in the letters reveals The Budget's editors to be sponsors of Amish literacy, engaged, as Brandt puts it, "in ceaseless processes of positioning and repositioning, seizing and relinquishing control over meanings and materials of literacy pas part of their participation in economic and political competition" ("Sponsors of Literacy" 562). None of my interview participants were troubled that the Amish and Mennonite international newspaper is edited and regulated by English outsiders. Since being an insider is so important to this community, it is surprising to me that the outsider status of The Budget's editorial staff is not an issue. I find this scenario to be problematic: a text for Amish by Amish, edited by non-Amish. But again, this concept follows the trend of values informing literacy practices. The Amish readers and writers for The Budget depend upon this partnership with the nonAmish newspaper and its editors because without the non-Amish technology, the paper would not exist. In return, the non-Amish editors and employees benefit from the enormous circulation of The Budget's Amish and Mennonite edition.

While there are no instructions in the actual paper for contributors to The Budget as one would find in an editorial section of a newspaper, scribes in Hanley told me that there are rules and standards which are given to each scribe upon taking on the duties. Scribes are clearly following a formula, and Samuel told me that he formats his letters 
according to this formula before he faxes them to The Budget office every Monday. Each letter begins with the date, location of scribe, and the name of the specific congregation. For example, Samuel's headings appear as follows:

Hanley, $\mathrm{OH}$

Valley View Mennonite

March 17, 2008

As I already discussed, the scribes seem to start letters with this convention as a way to establish credibility among an audience who values, as Fishman shows, familiarity as source of authority (45).

Weather is most commonly the first topic covered in the letters. Weather is written about in the narrative of the community's life. For example, Mrs. Ervin Yutzy says "We got another nice layer of snow last night so the yard had to be graded again" (21 Feb 2007, 13). Vernon Masts writes "Our cold spell has come to an end now. We had some rain and most of the snow is gone, too. Now we have mud, which isn't so nice" (28 Feb 2007, 33). Joseph's November 5, 2008 letter states, "We've just had the first frost of the fall. Deer hunters are getting all excited about that big one out there. Quite a few have been shot with the bow already. It's a good thing we don't depend on deer burgers in this house or we would be starving" (25).

These "weather reports" are unlike mainstream journalistic descriptions such as "cool, with light patches of fog," but instead are presented as part of the narrative of community life.

After weather, the letters most often move on to church business. Lee and Ruth Ann Hostetler of Cottage Grove, TN report in their 28 February 2007 letter that "this morning visitors in church were the Dean and Elva Farmwald family from Monticello, 
Ky; Alma Petersheim, local; and Jonathan and Karen Weaver from Orrville, Alabama"

(36). Sometimes church business includes information about community members traveling to other churches to give sermons, as Elmer and Cora Nisly's letter from Hutchinson, KS demonstrates: "Oren Yoders went to Labette Co. to preach at Cornerstone Church on Sunday morning. On Feb. 27 they have plans to leave for China for a pastoral visit with his sister Frieda Yoder who teachers English in their school" (28 Feb 2007, 36).

After church business, the writers detail what Barton and Hamilton call "local life," and for the Amish community, this includes births, deaths, tragedies, happy events, and community meetings that I have detailed above (Local Literacies 119). Scribes Joseph and Luke both explained that they saw this section as the most important part of their jobs as scribes. Luke said, "It's important to write about accidents, births, visitors, sickness, and weddings. That's what people want to know about." Joseph said, "the most important parts of the letter are church news, baby news, wedding news, and any deaths." It is interesting to note that the information in these sections rarely includes information about the author's own family, which brings attention to the term "scribe." Amish writers for The Budget use this word to describe themselves, and this term coupled with the inclusion of information in the letters emphasizes that the writers see their job not only as a social act, but also as a recorder of community news. "Scribe" suggests that the writers are reporting facts as the community would want them to without interpretation or additional commentary, and the uniformity of the letters suggests that the Amish community as a whole has approved of the format and consistent content. The 
term "scribe" may also refer to biblical scribes and therefore contribute further to the Amish ethos of religious devotion regularly present in the paper.

Scribes' letters are regulated (or edited) in ways beyond those which are dictated by the editors. Scribes rarely use German words except in the case of the word gma which, as Samuel told me, means church district. Occasionally, though, a scribe will slip in a German word or phrase, and in these cases, readers can be certain that another scribe or a reader contributing to "Information Please," a section I will discuss later in this section, will object to this practice. For example, one reader reminded the scribe from Dundee, $\mathrm{OH}$ to refrain from inserting German phrases "so everyone can read" (28 Feb 2007, 33). When I asked Samuel what he thought this reader meant by "everybody," he said, “probably the Mennonites who don't speak Old German or Pennsylvania Dutch, the English editors, or you people." This reader-generated reminder to follow the conventions of the paper illustrates that the readers are as committed to the coherency of the text as scribes and editors.

An important section of The Budget that helps to make it an important source of information for Amish and Mennonite readers is the "Information Please" column found on page 33 each week. This column includes both questions and answers written by readers of the paper. The content and organization of this section is not as uniform as the letters written by scribes. Some of these entries are addressed to specific scribes in reply to something they've said in their letter from the prior week. Sometimes, these entries are addressed to "anyone" or to "someone out in Budgetland." These entries are the ones in which the writers are seeking help, advice, items, recipes, et cetera. Some examples of these include home remedies or housekeeping tips-the sort of thing you'd see on the 
“Ask Heloise" page in Good Housekeeping Magazine. Tips that have appeared in recent issues of The Budget include a home remedy for killing weeds (3 Sept 2008); advice for how to can lard (15 Oct 2008); instructions on how to make sauerkraut in jars (12 Nov 2008); and instructions for caring for pecan trees (12 Nov 2008). In other entries, writers ask for products or material things. Some of these questions include: how to get an equipment catalogue (29 Oct 2008); where to find a hand crank 2 quart ice cream freezer (29 Oct 2008); to see if anyone has a specific children's book (3 Sept 2008); where can one find a more absorbent and long-lasting diaper cloth (10 Sept 2008); to see if anyone has a copy of a manual for their sewing machine the author may borrow (10 Sept 2008). I include this long list of examples to give readers a sense of the diversity of topics discussed in "Information Please."

Most often, "Information Please" is used to inquire about and give advice on how readers have dealt with the illnesses and medical needs of themselves and their family members. A reader submitted this advice to the September 10, 2008 issue: "Drink a glass of ice water if your sugar diabetes get high." The October 15, 2008 issue features questions about remedies for sleep apnea, memory loss, and allergies. Entries seeking medical advice are so prevalent in "Information Please" that editors include the following statement: "we strongly recommend that you contact your own doctor before using any home remedies suggested by our readers in this column." The fact that so many Budget readers use this outlet as a source of information points once again to the credibility and authority that comes with familiarity; in other words, because Amish people are the source, the advice is more trustworthy. 
Because The Budget is written for readers of the Anabaptist faith by members of the same faith, readers can rely on the content of The Budget to be consistent with their morals and values. As a result, The Budget is a source of entertainment for Amish and Mennonite readers. This statement, however, is a controversial one. Some of the scribes I interviewed for this study did not think the purpose of their work was to entertain. Joseph, for example, said that as a writer, he hopes readers "accept him as he is" and that he writes to supply news, "not to impress anybody." Similarly, Luke said that while he occasionally uses humor in his letters, the purpose was not to entertain but to inform readers. Readers Adam and Faith also insisted that The Budget is a news source, not an entertainment source.

But the use of The Budget as a source of entertainment is undeniable. Writers often include stories intended to amuse readers. Kathy Beachy's October 15, 2008 letter serves as an example:

Diane Beach was unable to make the trip. She had been fighting a strep infection for several stays, and by Tues. she was unable to swallow even water. After a call to the family doctor, Kenny took her to the emergency room for surgery to lance an abscess that was blocking her throat. The abscess is gone now, but the memory seems to be just about as painful. Diane described the procedure, which was done without sedation, and, in a brief but pardonable departure from her usual stand on the doctrine of nonresistance, suggested that it would bring her a profound sense of gratification to perform a similar procedure on the doctor. (36) 
Another example comes from Nathan and Barbara Lehman from Worthington, Indiana who wrote in their December 26, 2007 letter:

The Christmas season brings a lot of excitement to youngsters, looking forward to gifts. In their daily devotions yesterday morning, Freeman Yoder was praying for God's presence throughout the day. Four-year-old Lanae poked her mom and whispered, "Daddy prayed for presents!" (36) And while he insists that he doesn't like to tell many humorous stories in his letters, Hanley scribe Luke included this story in his September 24, 2008 letter: "At 1:30 on Sun. morning the rusted bottom of Andy's shaving cream can let loose. Ask Katie about cleaning walls on a Sun. morning" (17).

These humorous stories provide not only a form of entertainment that Amish readers can depend on to be consistent with their values, but Budget letters also create a shared text over which Amish community members can bond. Naomi told me, for example, that she circles stories for her daughter to read. Many community members shared that they discuss the stories they read in The Budget with neighbors, family, and friends. Fisher illustrates this trend in her discussion of a conversation about Die Botschaft between several Amish women. She says:

The Fishers, their friends, and their relatives frequently talk about individual scribes' letters and particular reported events, using the paper as a link both to the larger community and to each other. For example, Lydie Fisher, who lives several hours further away from Lancaster than Anna, reads the same scribes Anna does (those they both know from their Lancaster County days) before scanning the rest of the paper, a fact they 
discovered accidentally during a conversation about what they had read the previous week and one that set both women laughing. (43)

Reading Amish news, then, is a highly social activity that is associated with, as Barton and Hamilton would say, the domain of home and community ("Literacy Practices" 11). This makes what Barton and Hamilton call the "literacy event" of reading The Budget unlike pleasure reading in mainstream society ("Literacy Practices" 8). Pleasure reading is often seen as an anti-social activity by mainstream readers, such as the couple described by Barton and Hamilton in Local Literacies when they write, "Lynne's husband was sometimes annoyed with her reading, saying it cut down on their time together. Watching television or videos together, on the other hand, was seen as a social activity" (158). The Budget, then, serves the Amish community much like television or videos serve mainstream American audiences by giving consumers a common text or source of entertainment.

In this chapter, I have argued that The Budget is a text that helps to create community among a population of readers who not only depend upon this community identity to maintain their heritage and faith but also need a community building text because they cannot depend upon the community-building texts mainstream audiences use such as blogs, e-mail, websites, television shows, movies, et cetera. This text, then, is a result of literacy practices determined and shaped by the community's values.

It is easy to see, then, why The Budget is an extremely important text to the Amish, second only to The Bible. Like the models of education and language learning in the Amish community, The Budget is a text that demonstrates once again that literacy practices are shaped by the values of the community. The scribes who write for The 
Budget take care to portray their community in a way that pays respect to those living in the community. Conventions created both by scribes and editors construct The Budget as a unified, coherent, and trusted text that has been part of the Amish community since 1890. Community members are brought together by this text that serves as a source of both entertainment and news. In the following chapter, I discuss the implications my study offers for literacy studies and give suggestions for future work. 


\section{CHAPTER FIVE}

\section{"WHY DO YOU WANT TO KNOW ABOUT OUR READING AND WRITING?" CONCLUSIONS, IMPLICATIONS, AND REFLECTIONS}

This dissertation sought to answer questions about the nature of Amish literacy practices in Southeast Ohio. First, I wanted to understand what counts as important, meaningful, or worthwhile literacy in this Amish community and for what purposes does this community value literacy. Second, I hoped to find how Amish literacy helps to define a sense of Amish self. How do Amish texts and Amish reading reflect the essence of being Amish? Third, I worked to understand how languages (English, Pennsylvania Dutch, and Amish German) are treated in the community. How do the speakers of these languages regard each language? How is each language tied to Amish identity? How are these languages treated in regard to the learning of reading and writing? Finally, I aspired to know what role The Budget plays in the lives of the Amish men, women, and children living in Hanely. How are scribes regarded by other community members? How is a community scribe chosen? What motivates or dictates the content and form of letters that appear in The Budget?

The interviews and my study of The Budget revealed that Amish literacy practices are shaped and informed by what is valued most in Amish communities: faith and community. The influences of these two values can be seen in the model of Amish 
parochial education where students are taught to help one another learn to speak, read, and write English. Amish schools, churches, and leadership are modeled after the ideal of working together and collaborating as a community. Amish languages also follow in this pattern, since the Pennsylvania Dutch and Amish German languages are preserved as a way of maintaining and sustaining faith and heritage. While the English language is valued among members of the community for its ability to unite Amish and non-Amish neighbors, it is also recognized by the Amish as the language of economics and business. The Amish, despite their attempts to live separately from mainstream society, have adapted many prevalent attitudes about the value of English—and English only-in American society, and these attitudes have affected their literacy practices in visible ways. Students at Amish parochial schools are educated only in English with the slight exception of Friday afternoon Amish German lessons. Mennonite denominations of the Anabaptist faith have discontinued any use of Pennsylvania Dutch or Amish German education in hopes of creating an all-English speaking religious community. Young adults recognize and acknowledge that while Amish German is the language of their religion, they do not read the language as well as they would like or as well as their parents and grandparents do. Moreover, the influence of community and religious values can be seen in the Amish community's major newspaper, The Budget. Budget letters are written by scribes to represent their entire communities, and community members respect Budget scribes for this service. The Budget is seen as a trustworthy source of information and details valued by Amish readers. And even the act of reading The Budget is often a communal event that unites readers near and far. 


\section{Implications}

This dissertation argues that literacy, already known as a normalizing force (Goody and Watt), has so much influence on the lives of readers and writers that even the Amish, a community who lives by the principal of existing separate from the mainstream, are normalized by literacy. Even the Amish who have refused to adapt to so many American ideals cannot deny the importance of reading, writing, and speaking English in the United States. But the ways in which the Amish have adapted to this normalization, as I have shown, reflect the values central to their beliefs and traditions, or as Barton and Hamilton put it, "literacy fits in with other resources and practices available to groups" (Local Literacies 225). To put it another way: I stated at the beginning of this chapter that one of the questions I wanted to answer with this study was "how does Amish literacy help to define a sense of Amish self?" What I found instead was that the sense of Amish self defines Amish literacy.

The findings of this dissertation complicate Brandt's concept of the sponsor of literacy which she defines as those who "who enable, support, teach, model, as well as recruit, regulate, suppress, or withhold literacy - and gain advantage by it in some way" ("Sponsors of Literacy" 556). The Amish model of collaborative education illustrates an element of this exchange not yet treated by literacy scholars, the "pay it forward" model, which as I show, creates a cycle where those, in Vygotskian terms, who have reached a high level of developmental maturation help those at lower levels just as they had been helped during their maturation process without any individual advantage other than pleasing their mentors. 
While I did not seek to explicitly apply my dissertation to the teaching of composition, the results of this research have indeed informed my teaching. First, my findings have led me to think more specifically about how students are normalized by mainstream literacy practices (specifically social networking sites, popular weblogs, and popular novels) and how students' values inform their literacy practices. Second, I am convinced more than ever that ethnographic inquiry is beneficial to students at all levels. Student writers can learn a lot about the research process through this kind of fieldwork, and leaving the academy to do literacy research can be an empowering experience for students who have difficulty contributing to conventional academic conversations. In other words, students who struggle to produce scholarship based mostly on information found in books may find they have more to contribute to academic conversations when they collect data and write about their findings. Third, my experience with this project encourages me to use collaborative projects in my classes despite the resistance I often receive from students. The Amish community has great success with their collaborative model, and I am convinced that collaboration is a skill beneficial to the personal and professional lives of mainstream students. I am encouraged to weather the resistance and work to understand why the collaborative model works in Amish communities and how I can transfer this collaborative environment into my mainstream classes.

\section{Reflections}

One of my goals for this dissertation, as I mentioned in chapter one, was to engage with the Amish community in a way that was ethical, reflexive, and productive both for my research and relationships I developed with participants. I believe that I 
accomplished this goal, and in hindsight I realize that my success in securing productive interviews with participants was due at least in part to my respect for the community's beliefs, time, and individuals. As other researchers of the Amish have shown, it is not easy for outsiders like myself to gain access to individual community members (Fishman; Hostetler; Huntington). The great success of this dissertation, I argue, is that I established relationships and contacts I can depend on for, I suspect, a career full of literacy research.

There were, however, some complications that led to shortcomings in this dissertation. The first of these shortcomings is related to time. I spent three weeks collecting interviews in Hanley and devoted two full days to asking follow-up questions. While this period of time was long enough to collect 25 interviews; attend several community events including an auction and a wedding; visit several Amish businesses, homes, and schools; and develop relationships with several participants, I feel that I need to revisit each participant whose words appear in this dissertation and review our interviews more thoroughly before publishing any further information from this project to ensure that I have represented their views fairly. Since tape recorders were not used to record participants' responses, I feel that allowing participants to read my interpretation of their words is the only way to ensure that I am representing them ethically and correctly.

Second, in future work, I will not group Mennonites and the Amish under one category. As I have shown, Mennonites have embraced the use of technology in their lives, and they have also abandoned the Pennsylvania Dutch and Amish Germans languages. These facts mean that Mennonite literacy practices are informed and shaped 
by very different life experiences. Linking these two groups so intimately as I have done in this dissertation may have led to some imprecise claims about one or both groups. In the future, I will treat the two groups separately, as I believe the field of literacy studies has much to learn from both groups.

Finally, if I had this study to do over, I would approach the design very differently. I would have asked Matthew, the community bishop, for help from the beginning. Matthew could have helped me create an informed consent form that made more sense to the community. In planning for this study, I underestimated the amount of help members of the Hanley Amish community would be willing to provide to me. If I knew then what I know now, I would have relied on their expertise and kindness in helping me create a better study. These design elements, then, would include an IRB consent form written with an Amish audience in mind rather than the IRB audience and would not have included information about computers, telephones, or other items or concepts foreign to most participants.

\section{Further Research}

In this dissertation, I have used what may seem like an extreme sample group, the Amish, to show just how normalizing literacy can be. If literacy practices normalize even the Amish, imagine how mainstream consumers of popular literacy are transformed. Literacy scholars must continue to study how readers and writers are influenced and normalized by attitudes about literacy. In addition, we must strive to understand the outcome of this normalization. In the case of the Amish, the effect could be threatening to the community's native language. To a community who so closely ties language to 
identity and heritage, this change would be devastating. My future research in this area will treat Amish and Mennonite communities separately since, as I mentioned in the above paragraph, attitudes about language are very different in these communities.

Literacy scholars must also continue to examine the ways in which communities' values shape and inform the community's literacy practices. Scholars of literacy studies have already acknowledged how values or institutions like capitalism, middle class work ethic, and faith inform dominant ideas about literacy in mainstream culture (Stuckey; Brandt; Street; Barton and Hamilton). But my research suggests that literacy practices can be shaped by even more personal, micro-level values systems. This data points to an area ripe for research that could help teachers of writing better understand how students' literacy practices are informed by their values and how to harness these values to help students become better readers and writers.

Finally, there is evidence that the Amish have had great success with classroom collaboration as a pedagogical tool. Now that I have developed relationships and contacts within the Amish community, I plan to return to Hanley to spend time in the four private parochial schools. My future research will focus on how collaboration-a major value of the Amish community-is used both implicitly and explicitly in classroom instruction. This research will seek to answer questions such as:

1. How does classroom collaboration operate in a community where collaboration is valued in all aspects of life?

2. Since collaboration plays such an instrumental role in their lives outside of school, are Amish students less resistant to classroom collaboration than mainstream students? 
3. Do Amish students initiate classroom collaboration, or are they always directed to collaborate?

4. In college writing courses (and especially in business writing courses), teachers often tell students that collaborative assignments are good practice for workplace writing. Do Amish students see their classroom collaborative practices as preparation for their lives as Amish adults living in communities that value collaboration?

5. The Amish have clearly adopted an alternative method of educating their children. How does this model compare with other alternative methods of education, such as Free Skools, Democratic Schools, Unschooling, and Montessori Schools?

I also plan to examine how power and institutions like the Amish church control and contextualize Amish literacy practices. Most importantly, my vision for future research starts with meeting individually with community members like Matthew, the community scribe who helped me rethink my interview approach; Caleb, the blacksmith who showed great concern for the state of Pennsylvania Dutch; Samuel, the Mennonite scribe who took such care to answer my questions carefully; Anna and Daniel, the Mennonite couple who recognized how language divides the Amish from the Mennonites; and Hannah, the school teacher, to develop a research agenda for the future. 


\section{REFERENCES}

Adkins, Tabetha. Ethnographic Inquiry. $\leq \mathrm{http}: / /$ www.adkinsdiss.com/ $>$

----. “"Making Waves' In Communities We Study: Ethnographic Research Ethics and Amish Values." Conference on College Composition and Communication. San Francisco Hilton, San Francisco, CA. 12 March 2009.

Amish Country, Ohio. 2008. Holmes County Chamber of Commerce. 26 June 2008.

$<\underline{\text { http://www.visitamishcountry.com/ }>}$

Anderson, Benedict. Imagined Communities. 1983. London: Verso, 2006.

Alexander, Kara Poe and Joanna Wolfe. "The Computer Expert in Mixed-Gendered

Collaborative Writing Groups." Journal of Business and Technical Communication $19.2(2005), 135-170$.

Associated Press. "Amish Population Doubling in Numbers." WLKY Louisville Family News. 21 Aug 2008. WLKY. 5 Sept 2008. <http://www.wlky.com/family/ $\underline{17253446 / \text { detail.html }}$.

Bakhtin, M. M. The Dialogic Imagination. Trans. C. Emerson and M. Holquist. Austin: U of Texas P, 1981.

Barton, Mary and David Hamilton. Local Literacies: Reading and Writing in One Community. London: Routledge, 1998.

Besmeres, Mary. "Language and Emotional Experience: The Voice of Translingual 
Memoir." Bilingual Minds: Emotional Experience, Expression, and

Representation. Ed. Aneta Pavlenko. Clevedon, UK: Multilingual Matters, 2006. $34-58$.

Besnier, Niko. Literacy, Emotion, and Authority: Reading and Writing on a Polynesian Atoll. New York: Cambridge UP, 1995.

Black, Edwin. "The Second Persona." In Landmark Essays on Rhetorical Criticism. Ed. T.W. Benson Davis, CA: Hermagoras P, 1993.

Brandt, Deborah. Literacy in American Lives. New York: Cambridge UP, 2001.

---. "Sponsors of Literacy." College Composition and Communication 49.2 (1980:

165-85. Rpt. in Literacy: a Critical Sourcebook. Ed. Ellen Cushman, et al. 165-86. Boston: Bedford/ St. Martin's, 2001.

---. “'Who's the President?': Ghostwriting and Shifting Values in Literacy." College English 69.6 (2007): 549-571.

Bruffee, Kenneth A. Collaborative Learning: Higher Education, Interdependence, and the Authority of Knowledge. Baltimore: Johns Hopkins UP, 1993.

---. "The Brooklyn Plan: Attaining Intellectual Growth through Peer-Group Tutoring." Liberal Education 64 (1978): 447-69.

Burrow-Flak, Elizabeth. "From Castles in the Air to Portfolios in Cyberspace: Building Community Ethos in First-year Rhetoric and Composition." Weaving a Virtual Web: Practical Approaches to New Information Technologies. Ed. Sibylle Gruber. Urban, II: NCTE, 2000.

Caldwell-Harris, Catherine, Marianna Staroselsky, Nadya Vasilyeva, Victoria Rukovets, 
and Victoria Choate. Psychophysiological Studies of Emotional Arousal to Bilingual Speakers' First and Second Languages. Annual Meeting of the Cognitive Neuroscience Society in New York. 7 May 2008.

Coles, Nicholas. "Joe Shakespeare: The Contemporary British Worker-Writer Movement." Popular Literacy: Studies in Cultural Practices and Poetics. Ed. John Trimbur. Pittsburgh: U of Pittsburgh P, 2001. 189-208.

Crystal. David. Language Death. Cambridge: Cambridge UP, 2000.

Davies, Charlotte. Reflexive Ethnography: A Guide to Researching Selves and Others. London: Routledge, 1999.

Dewaele, Jean-Marc. "Expressing Anger in Multiple Languages." Bilingual Minds: Emotional Experience, Expression, and Representation. Ed. Aneta Pavlenko. Clevedon, UK: Multilingual Matters, 2006. 118-151.

Donehower, Kim, Charlotte Hoff, and Eileen E. Schell. Rural Literacies. Carbondale, IL: Southern Illinois UP, 2007.

Duffy, John M. Writing From These Roots: Literacy in a Hmong-American Community. Honolulu: U of Hawaii P, 2007.

Fishman, Andrea. Amish Literacy: What and How it Means. Portsmouth, NH: Heinemann, 1988.

Fishman, Joshua A. "'English Only': Its Ghosts, Myths and Dangers." 1988. Language Loyalty, Language Planning and Language Revitalization: Recent Writings and Reflections From Joshua A. Fishman. Nancy H. Hornberger and Martin Pütz, Eds. Clevedon, UK: Multilingual Matters, 2006.

Flynn, Elizabeth A. "Composing as a Woman." College Composition and 
Communication 39 (1988): 423-35.

Gere, Anne Ruggles. "Common Properties of Pleasure: Texts in Nineteenth-Century Women's Clubs. "The Construction of Authorship: Textual Appropriation in Law and Literature. Eds. Martha Woodmansee and Peter Jaszi. Durham, NC: Duke UP, 1994. 383-99.

Goody, Jack. The Power of the Writing Tradition. Washington, DC: Smithsonian Institution $\mathrm{P}, 2000$.

--- and Ian Watt. "The Consequences of Literacy." Perspectives on Literacy. Eds. Eugene R. Kintgen and Barry M. Kroll. Carbondale, IL: Southern Illinois UP, 1988.

Goodman, Yetta. How Children Construct Literacy Piagetian Perspectives. Newark, DE: International Reading Association, 1990.

Guerra, Juan C. Close to Home: Oral and Literate Practices in a Transnational Mexicano Community. New York: Teachers College P, 1998.

Harroff, Stephen Bowers. The Amish Schools of Indiana: Faith in Education. West Lafayette, IN: Perdue UP, 2004.

Heath, Shirley Brice. Ways with Words: Language, Life, and Work in Communities and Classrooms. New York: Cambridge, 1993.

Heloise. "Ask Heloise" Good Housekeeping. Feb. 2009: 32.

Herrmann, Mareike. “Amish Language Project?” E-mail to Tabetha Adkins. 12 May 2008.

Horner, Bruce and John Trimbur. "English Only and U.S. College Composition." College Composition and Communication 54.3 (2003): 594-630. 
Hostetler, John A. Amish Society. $4^{\text {th }}$ ed. Baltimore: Johns Hopkins UP, 1993.

--- and Gertrude Enders Huntington. Amish Children: Education in the

Family, School, and Community. Fort Worth: Harcourt Brace Jovanovich, 1992.

Huntington, Gertrude Enders. Amish in Michigan. East Lansing, MI: Michigan State

UP, 2001

Hurst, Charles. "Amish Language Project?'” E-mail to Tabetha Adkins. 9 May 2008.

Iancu, Anca. Personal Interview. 7 June 2008.

Joseph, John E. Language and Identity: National, Ethnic, Religious. New York:

Palgrave, 2004.

Kirsch, Gesa. Ethical Dilemmas in Feminist Research: The Politics of Location, Interpretation, and Publication. Albany, NY: State U of New York P, 1999.

-.-. "Reflecting on Collaboration in Feminist Empirical Research: Some Cautions."

Feminist Empirical Research: Emerging Perspectives on Qualitative and

Teacher Research. Ed. Joanne Addison and Sharon James McGee. Portsmouth,

NH: Boynton/ Cook, 1999. 158-62.

Koven, Michèle. "Feeling in Two Languages: A Comparative Analysis of a Bilingual's Affective Displays in French and Portuguese." Bilingual Minds: Emotional Experience, Expression, and Representation. Ed. Aneta Pavlenko. Clevedon, UK: Multilingual Matters, 2006. 59-83.

Labov, William. Principles of Linguistic Change: Social Factors. Oxford: Blackwell, 1994.

Levi-Strauss, Claude. Tristes Tropiques. Trans. J. Russell. New York: Anthem, 1964. Lofty, John S. "Time to Write: Resistance to Literacy in a Maine Fishing Community." 
The Right to Literacy. Eds. Andrea A. Lunsford, Helene Moglen, and James

Slevin New York: Modern Language Association, 1990. 39-49.

Lunsford, Andrea and Lisa Ede. Singular Texts/Plural Authors: Perspectives on Collaborative Writing. Carbondale, IL: Southern Illinois UP, 1990.

Miles, Matthew B. and A. Michael Huberman. Qualitative Data Analysis. $2^{\text {nd }}$ ed. Thousand Oaks, CA: Sage, 1994.

New King James Bible. Nashville: Thomas Nelson, 1997.

Newkirk, Thomas. "Seduction and Betrayal in Qualitative Research." Ethics and Representation in Qualitative Studies of Literacy. Ed. Peter Mortensen and Gesa Kirsch. Urbana, IL: NCTE, 1996. 3-16.

Old Order Book Society, Old Order Amish School Committee, and Old Order Mennonite School Committee. Standards of the Old Order Amish and Old Order Mennonite Parochial and Vocational Schools of Pennsylvania. Gordonville, PA:

Gordonville Print Shop, 1973.

Ong, Walter J. Orality and Literacy. 1982. London: Routledge, 2002.

Pavlenko, Aneta. "Bilingual Selves." Bilingual Minds: Emotional Experience, Expression, and Representation. Ed. Aneta Pavlenko. Clevedon, UK: Multilingual Matters, 2006. 1-33.

Perl, Sondra. "Early Work on Composing: Lessons and Illuminations." History, Reflection, and Narrative: The Professionalization of Composition 1963-1983.

Eds. Mary Rosner, Beth Boehm, and Debra Journet. Norwood, NJ: Ablex, 1999. Powell, Katrina. The Anguish of Displacement : The Politics of Literacy in the Letters of 
Mountain Families in Shenandoah National Park. Charlottesville : U of Virginia P, 2007.

--- and Pamela Takayoshi. "Accepting Roles Created for Us: The Ethics of Reciprocity." College Composition and Communication 54.3 (2003): 394-422.

Pratt, Mary Louise. "Fieldwork in Common Places." Writing Culture: The Poetics and Politics of Ethnography. Ed. James Clifford and George E. Marcus. Berkeley, CA: University of California P, 1986. 27-50.

Prendergast, Catherine. Buying Into English: Language and Investment in the New Capitalist World. Pittsburg, PA: U of Pittsburg P, 2008.

Ramazanoglu, Caroline. Feminist Methodology: Challenges and Changes. Sage: London, 2002.

Rathbun, Keith, ed. The Budget. Sugar Creek, Ohio: Sugar Creek Budget Publishers, 2007-08.

Roof, Judith and Robyn Wiegman. Who Can Speak?: Authority and Critical Identity. Urbana, IL: U of Illinois P, 1995.

Scribner, Sylvia and Michael Cole. The Psychology of Literacy. 1981. Cambridge, MA: Harvard, 1999.

Sohn, Katherine Keller. Whistlin' and Crowin' Women of Appalachia: Literacy Practices Since College. Carbondale, IL: Southern Illinois UP, 2006.

Street, Brian. "The New Literacy Studies." Cross-Cultural Approaches to Literacy. Ed. Brian Street. London: Cambridge UP, 1993. 1-21.

Stuckey, J. Elspeth. The Violence of Literacy. Portsmouth, NH: Heinemann, 1991. 
Sullivan, Patricia. "Ethnography and the Problem of the 'Other'." Ethics and Representation in Qualitative Studies of Literacy. Ed. Peter Mortensen and Gesa Kirsch. Urbana, IL: NCTE, 1996. 97-115.

---. "Feminism and Methodology." Methods and Methodology in Composition Research. Ed. Gesa Kirsch and Patricia Sullivan. Carbondale, IL: Southern Illinois UP, 1992. 37-61.

--- and Peter Mortensen, Eds. Ethics and Representation on Qualitative Studies of Literacy. Albany: State U of New York P, 1996.

U.S. Farms: Numbers, Size, and Ownership. United States Department of Agriculture Economic Research Service. 18 March 2009.

http://ers.usda.gov/publications/EIB12/EIB12c.pdf?

Vygotsky. Lev. Mind in Society: The Development of Higher Psychological Processes. Eds. Michael Cole, et al. Cambridge, MA: Harvard UP, 1978.

Wisconsin v. Yoder, 406 U.S. 205 (1972), Supreme Court of the United States. In Depth Write-up of the Supreme Court Case. Retrieved on 2008-06-10.

Yagelski, Robert. Literacy Matters: Writing and Reading the Social Self. New York: Teachers College, 2000.

Yancey, Kathleen Blake. "Feminist Empirical Research." Feminist Empirical Research: Emerging Perspectives on Qualitative and Teacher Research. Eds. Joanne Addison and Sharon James McGee. Portsmouth, NH: Boynton/Cook, 1999. 


\title{
APPENDIX A
}

\section{ADULT INTERVIEW QUESTIONS}

\author{
Dissertation Interview Questions \\ Adult
}

1. Could you explain to me how you came to know two different languages? (This question is aimed at making the subject feel like the expert who is teaching me about their culture.)

2. Can you remember reading and writing when you were a child?

3. How much English did you know when you went to school?

4. Did you enjoy school? What are your memories of school?

5. What do you see as the benefits of living in a bilingual community? Do you see these effects as ones that could be beneficial to other, non-Amish communities?

6. Will you tell me about your work? How does your reading and writing knowledge help you at work?

7. I'm really interested in learning about The Budget. What can you tell me about the paper?

8. Have you ever written a letter for the paper? What motivated you to do that? Did someone ask you to? Were you reporting a specific event?

9. How much time do you spend reading The Budget each week? Do you the whole paper, or do you select specific sections to read? How do you decide which sections you'll read?

10. Why do you think the letters in The Budget are written in English?

11. Who do you see as the audience for The Budget? 


\section{APPENDIX B \\ CHILD INTERVIEW QUESTIONS}

1. I'm learning that everybody in your community speaks two languages. Can you tell me about that?

2. What do you learn at school? What language do you speak at school?

3. Do you like learning English? Why do you think your teacher wants you to learn English?

4. Why do you think it's important to go to school?

5. What language does your teacher use? (Ask questions that get to the authority each child recognizes with each language. i.e. teacher uses English when she's angry, et cetera.)

6. What do you think you'll be when you grow up? How will what you've learned at school help you be the best (whatever child wants to be, whether it be farmer, mother, wood-worker, baker, et cetera) you can be?

7. Do you read (or do your parents/siblings read to you) The Budget when it arrives every week? Have you ever read about yourself or your family in The Budget?

8. Do you think you'll write for the Budget when you're grown up? (If yes,) what do you think you'll write about? 


\section{APPENDIX C SCRIBE INTERVIEW QUESTIONS}

1. How did you come to write for the Budget?

2. Walk me through your thought process while composing your letters for the Budget. How do you decide what to include?

3. Words used by English people to describe the letters:

- community minded

- detailed

- details in context of everyday life

- for an audience you know

would agree with this assessment, or do you think we misunderstand your writing?

4. Conventions of letters- enforced by Budget editors? Why are the editors of the Budget English? How did that come to be? Why the guidelines? May I see guidelines?

5. What do you see as being the purpose of the letters?

6. How do you want to come across to your readers?

7. How do you want your readers to feel after reading your letter?

8. What does gma mean? 


\section{APPENDIX D TEACHER INTERVIEW QUESTIONS}

1. Regular adult interview questions.

2. How much English do your new students typically know upon coming to school?

3. What do you see as your primary goals for teaching?

4. How did you become a teacher? Did you always want to be a teacher?

5. What strategies do you use to help the students learn?

6. What kinds of reading and writing do the students do each day in class?

7. What kinds of reading and writing do you do for your work? 


\title{
APPENDIX E \\ INFORMED CONSENT FORM
}

\author{
Amish Literacy Practices in Southeast Ohio \\ Investigator(s) name \& address: Karen Kopelson (primary) and Tabetha Adkins \\ Site(s) where study is to be conducted: Patriot, Ohio \\ Phone number for subjects to call for questions: (502) 554-6556

\section{Introduction and Background Information}

You are invited to participate in a research study. The study is being conducted by Dr. Karen Kopelson and Tabetha Adkins. The study is sponsored by the University of Louisville, Department of English. The study will take place in Patriot, Ohio. Approximately 10-50 subjects will be invited to participate.

\section{Purpose}

The purpose of this study is to learn about the reading and writing of bilingual communities living in rural areas.

\section{Procedures}

In this study, you will be asked to answer questions asked by Tabetha Adkins. The questions asked by Tabetha Adkins will ask about language learning, reading and writing in the home, reading and writing at work, The Budget newspaper, and second language acquisition. Questions will not deviate from reading and writing. These questions would be asked and distributed during a five-week span of time during the spring of 2008 and would require approximately 30 minutes of time to complete. Anyone is welcome to decline to answer any question that may make them uncomfortable.

\section{Potential Risks}

There are no foreseeable risks other than possible discomfort in answering personal questions, but as with any research study, there may be unforeseeable risks. 


\section{Benefits}

The possible benefits of this study include contributing to knowledge regarding language learning and the teaching of reading and writing. The information collected may not benefit you directly. The information learned in this study may be helpful to others.

\section{Compensation}

You will not be compensated for your time, inconvenience, or expenses for your participation in this study. There are no foreseeable expenses for your participation in this study.

\section{Confidentiality}

Total privacy cannot be guaranteed. Your privacy will be protected to the extent permitted by law. If the results from this study are published, your name will not be made public. While unlikely, the following may look at the study records:

Office for Human Research Protections (OHRP)

Your identity will be protect in the following ways:

Your name will be changed to protect your identity

The name of your community will be changed to protect your community's identity

The data will be stored on a password-protected computer

\section{Voluntary Participation}

Taking part in this study is voluntary. You may choose not to take part at all. If you decide to be in this study you may stop taking part at any time.

\section{Research Subject's Rights, Questions, Concerns, and Complaints}

If you have any concerns or complaints about the study or the study staff, you have three options.

You may contact the principal investigator, Karen Kopelson, at (502) 852-2188.

If you have any questions about your rights as a study subject, questions, concerns or complaints, you may call the Human Subjects Protection Program Office (HSPPO) (502) 852-5188. You may discuss any questions about your rights as a subject, in secret, with a member of the Institutional Review Board (IRB) or the HSPPO staff. The IRB is an independent committee composed of members of the University community, staff of the institutions, as well as lay members of the 
community not connected with these institutions. The IRB has reviewed this study.

If you want to speak to a person outside the University, you may call 1-877852-1167. You will be given the chance to talk about any questions, concerns or complaints in secret. This is a 24 hour hot line answered by people who do not work at the University of Louisville.

This paper tells you what will happen during the study if you choose to take part. Your signature means that this study has been discussed with you, that your questions have been answered, and that you will take part in the study. This informed consent document is not a contract. You are not giving up any legal rights by signing this informed consent document. You will be given a signed copy of this paper to keep for your records.

Printed Name of Subject/Legal Representative

Signature of Subject/Legal Representative

Date Signed

Signature of Person Explaining the Consent Form

Date Signed

(if other than the Investigator)

Signature of Investigator

Date Signed

\section{LIST OF INVESTIGATORS}

Tabetha Adkins

Karen Kopelson

Department of English

Bingham Humanities 315

2211 South Brook

University of Louisville

Louisville, KY 40292

\section{PHONE NUMBERS}

(502) $554-6556$

(502) $852-2188$ 


\section{APPENDIX F}

\section{PARENTAL CONSENT FORM}

\section{Amish Literacy Practices in Southeast Ohio}

Investigator(s) name \& address: Karen Kopelson (primary) and Tabetha Adkins

Site(s) where study is to be conducted: Patriot, Ohio

Phone number for subjects to call for questions: (502) 554-6556

\section{Introduction and Background Information}

You/ your child are invited to participate in a research study. The study is being conducted by Dr. Karen Kopelson and Tabetha Adkins. The study is sponsored by the University of Louisville, Department of English. The study will take place in Patriot, Ohio. Approximately 10-50 subjects will be invited to participate.

\section{Purpose}

The purpose of this study is to learn about the reading and writing of bilingual communities living in rural areas.

\section{Procedures}

In this study, you (in this document, "you" refers to you or your child) will be asked to answer questions asked by Tabetha Adkins. The questions asked by Tabetha Adkins will ask about language learning, reading and writing in the home, reading and writing at work, The Budget newspaper, and second language acquisition. Questions will not deviate from reading and writing. These questions would be asked and distributed during a five-week span of time during the spring of 2008 and would require approximately 30 minutes of time to complete. Anyone is welcome to decline to answer any question that may make them uncomfortable.

\section{Potential Risks}

There are no foreseeable risks other than possible discomfort in answering personal questions, but as with any research study, there may be unforeseeable risks. 


\section{Benefits}

The possible benefits of this study include contributing to knowledge regarding language learning and the teaching of reading and writing. The information collected may not benefit you directly. The information learned in this study may be helpful to others.

\section{Compensation}

You will not be compensated for your time, inconvenience, or expenses for your participation in this study. There are no foreseeable expenses for your participation in this study.

\section{Confidentiality}

Total privacy cannot be guaranteed. Your privacy will be protected to the extent permitted by law. If the results from this study are published, your name will not be made public. While unlikely, the following may look at the study records:

Office for Human Research Protections (OHRP)

Your identity will be protect in the following ways:

Your name will be changed to protect your identity

The name of your community will be changed to protect your community's identity

The data will be stored on a password-protected computer

\section{Voluntary Participation}

Taking part in this study is voluntary. You may choose not to take part at all. If you decide to be in this study you may stop taking part at any time.

\section{Research Subject's Rights, Questions, Concerns, and Complaints}

If you have any concerns or complaints about the study or the study staff, you have three options.

You may contact the principal investigator, Karen Kopelson, at (502) 852-2188.

If you have any questions about your rights as a study subject, questions, concerns or complaints, you may call the Human Subjects Protection Program Office (HSPPO) (502) 852-5188. You may discuss any questions about your rights as a subject, in secret, with a member of the Institutional Review Board (IRB) or the HSPPO staff. The IRB is an independent committee composed of members of the University community, staff of the institutions, as well as lay members of the 
community not connected with these institutions. The IRB has reviewed this study.

If you want to speak to a person outside the University, you may call 1-877852-1167. You will be given the chance to talk about any questions, concerns or complaints in secret. This is a 24 hour hot line answered by people who do not work at the University of Louisville.

This paper tells you what will happen during the study if you choose to take part. Your signature means that this study has been discussed with you, that your questions have been answered, and that you will take part in the study. This informed consent document is not a contract. You are not giving up any legal rights by signing this informed consent document. You will be given a signed copy of this paper to keep for your records.

Printed Name of Subject/Legal Representative

Signature of Subject/Legal Representative

Date Signed

Signature of Person Explaining the Consent Form

Date Signed

(if other than the Investigator)

Signature of Investigator

Date Signed

LIST OF INVESTIGATORS

Tabetha Adkins

Karen Kopelson

Department of English

Bingham Humanities 315

2211 South Brook

University of Louisville

Louisville, KY 40292

\section{PHONE NUMBERS}

(502) 554-6556

(502) $852-2188$ 


\section{APPENDIX G}

\section{CHILD ASSENT FORM}

\section{Amish Literacy Practices in Southeast Ohio}

I am invited to be in a research study being done by Professor Kopelson and Tabetha Adkins. When a person is in a research study, they are called a "subject". I am invited because I am an Amish child living in Patriot, Ohio.

This means that I will talk with Tabetha Adkins about learning to speak English and what I learn at school. There may be some risks with this study. These risks are that I may not want to talk about school.

This study will last approximately twenty minutes. The benefit to me for participating in this study is nothing but helping other people teach English more like the way I have learned English.

My family, the professor, and the Shato family will know that I'm in the study. If anyone else is given information about me, they will not know my name. A number or initials will be used instead of my name.

I have been told about this study and know why it is being done and what I have to do. My parent(s) have agreed to let me be in the study. If I have any questions I can ask Professor Tabetha Adkins. She will answer my questions. If I do not want to be in this study or I want to quit after I am already in this study, I can tell the researcher and she will discuss this with my parents.

Printed Name of Subject

Signature of Subject

Date Signed

Printed Name of Parent/Guardian Signature of Parent/Guardian Date Signed

Printed Name of Investigator Signature of Investigator Date Signed 


\section{APPENDIX H}

May 8, 2008

\section{LETTER TO LUKE}

Hello, Mr. Troyer.

I'm working on a book for my doctorate degree, and the subject of my book is community reading and writing practices. Since you're a Budget scribe, I have a particular interest in talking to you about your writing. I'd like to ask you the following questions in an interview:

1. How did you come to write for The Budget?

2. How do you decide what to include in your weekly letter?

3. I've shown some Budget letters to some of my friends. The words they used to describe the letters were: community minded; detailed; details in context of everyday life; writing for an audience you know (people you've met). Do you think those descriptions are fair?

4. How do you want your readers to feel when they reader your Budget letter? What do you hope they think about you and the community you represent?

5. How much of The Budget do you read each week? How do you decide which articles to read?

6. I've been told that the editors of The Budget have given scribes strict guidelines. Can you tell me about that?

As you can see, my questions do not deviate from the topics of reading and writing. Also, since I work for a university, I am required to protect your identity and change your name and the name of your community. I'm also required to attain your signature on a very formal permission slip (that I'll attach to this letter for you to see). This permission slip is very thorough because I work at a university with a medical school, so I must go through the same process as doctors testing medicine on patients. The form just gives me permission to use your words - but not your name or your community's name. I know that you had an incident once where a man misquote you in the local newspaper and abused your trust. I want to assure you that if we talk I will not print anything in a newspaper and no one will ever know we talked. I respect the people in this community far too much - especially since so many have been so kind to the Shato family-and I would never do anything to make this community embarrassed or uncomfortable.

Thank you for your time. I hope you'll decide to talk to me.

Best wishes, Tabetha Adkins 


\section{CURRICULUM VITAE}

\section{Tabetha Adkins}

Tabetha.Adkins@louisville.edu

http://tabethaadkins.com/

\section{Education}

Ph.D. Rhetoric and Composition, University of Louisville, May 2009

Dissertation: "In the Wor(1)d but Not Of It": Amish Community Literacy in Southeast Ohio

Committee: Karen Kopelson (Chair), J. Carol Mattingly, Bronwyn T. Williams, Annette Harris Powell, and Katrina M. Powell

Graduate Certificate, Women's and Gender Studies. University of Louisville, 2009.

M.A. English, University of Louisville, 2005

B.A. English, Marshall University, 2003.

Minor: Women's Studies

\section{Publications}

"A Label Like Gucci, Versace, or Birkenstock: Sex and the City and Queer Identity." Televising Queer Women. Ed. Rebecca Beirne. New York: Palgrave, 2008. 109-119.

"Digital Mirrors: Multimodal Reflection in the Composition Classroom." Coauthored with Christopher Alexander, Patrick Corbett, Debra Journet, and Ryan Trauman. Computers and Composition Online. Spring 2008.

http://www.bgsu.edu/cconline/Digital_Mirrors/ 


\section{Presentations}

“"Making Waves' In Communities We Study: Ethnographic Research Ethics and Amish Values." Conference on College Composition and

Communication. San Francisco. March 2009.

"Writing Amish Realities to Create Identity." Conference on College Composition and Communication. New Orleans. April 2008.

"'What is this Thing Called Feminism?': Convergences and Contradictions in Popular and Academic Feminist Texts." Kentucky Philological Association. Louisville. March 2008.

"New Issue, Same Ethos: Pro Slavery Rhetoric of the 19th Century and Homophobic Rhetoric of the 21st Century." Feminism(s) and Rhetoric(s). Little Rock. October 2007.

"Authority Online: Issues of Authority in Online Writing Center Tutorials." National Conference on Peer Tutoring in Writing. Ann Arbor. November 2006.

“'Tell Me More' or 'Too Much Information': Personal Narratives in the Academy." Thomas R. Watson Conference on Rhetoric and Composition. Louisville. October 2006.

"Liberal Arts Education and the Problem of Proprietary Schools Curricula." Conference on College Composition and Communication. San Francisco. March 2005.

"Pre-Feminism Writing: Can We Call It Feminist?" Marshall University College of Liberal Arts Undergraduate Research and Creativity Conference. Huntington. 2002. 


\section{Awards}

CCCC Chairs' Memorial Scholarship. Conference on College Composition and Communication. 2009.

M. Celeste Jackson Nichols Professional Development Award. University of Louisville Women's Center. 2007.

John Sweetland Award. National Conference on Peer Tutoring in Writing. 2006.

Maier Writing Award. Upper Division Non-Fiction. Marshall University. 2004.

\section{Administrative Experience}

Assistant Director of Composition. University of Louisville (2007-present)

Assistant Director, 2008 Thomas R. Watson Conference in Rhetoric and Composition. University of Louisville (2007-present)

Assistant Director, University Writing Center. University of Louisville (2005-2007)

\section{Teaching Experience}

Graduate Teaching Assistant, University of Louisville. 2003-present.

Courses designed and taught at the University of Louisville:

Business Writing

Women in American Society

Women's Literature

Introduction to College Writing

Intermediate College Writing

English Instructor, Bellarmine University, Louisville, KY. 2006.

Designed and taught expository writing.

Writing Tutor, University of Louisville, 2003-2007

Assisted undergraduate students, graduate students, and faculty with writing both in face to face tutoring sessions and online e-mail and real-time chat consultations.

\section{Workshops Conducted}

Teaching Plagiarism 
Avoiding Plagiarism

Peer Review for Business Students

Peer Review for Psychology Students

Teaching Peer Review

Writing Effective Thesis Statements

Writing with Sources in the Humanities

Writing with Sources in the Social Sciences

\section{Technology Experience}

Designed and maintain composition program's website

Designed a database system to be used to organize and search small private library for English department faculty and graduate students.

Proficient in teaching and publishing with multimodal technology (digital audio/video recording and editing)

Experience operating and organizing University's virtual writing center

Experience w/ web page development (Plone, Adobe Cold fusion, HTML)

\section{Related Service}

Contributor, CompPile Indexes at http://comppile.tamucc.edu/index.php

Member, Grey's Bookstore Excellence in Teaching for Part-Time Lecturer Award

Committee

Reader, General Education Curriculum Committee Assessment Project. 2007

Member, English Graduate Organization, Fall 2003-present

Member, English Graduate Organization Executive Board, Fall 2006-Spring 2007

Member, Technology Committee, English Department, 2005-2007

Mentor to first year doctoral students, 2006-2009

Mentor to new teachers of composition, 2007-present

\section{Professional Associations}

The Coalition of Women Scholars in the History of Rhetoric

The Conference on College Composition and Communication

Council of Writing Program Administrators

International Writing Centers Association

National Council of Teachers of English

National Women's Studies Association 